\title{
CHARITABLE BEQUESTS AND WEALTH AT DEATH*
}

\author{
Anthony B Atkinson, Peter G Backus, and John Micklewright
}

\begin{abstract}
Charitable bequests are a major source of income for charities but surprisingly little is known about them. We propose a multi-stage framework for analysing the bequest decision and examine the evidence for Britain provided by new data on estates. The novelty of the framework is that it distinguishes between five different steps that lead to a charitable bequest. Our new data for Britain have the advantages of covering the whole population of non-trivial estates, in contrast to much of the US literature based on the small fraction of the population covered by estate tax returns, and of containing fuller information on charitable intent. We use this unique data set to explore the relationship with wealth at death of testacy, of leaving a charitable bequest, and of the form of the bequests.
\end{abstract}

Giving to charity at death is an age-old phenomenon and its importance is likely to grow. For charities, bequests are a major income source: in the UK, they make up about a quarter of donated income for the top 500 fundraising charities (CAF 2004: 22). Many governments seek to encourage charitable giving, and understanding its determinants is of considerable policy relevance.

For individuals, how to leave one's wealth is a decision unlike all others. We propose a multi-stage framework for the decision to leave a charitable bequest and examine evidence for Britain about charitable giving at death provided by new data on estates. The novelty of the framework is its distinction between the different steps leading to a charitable bequest. The individual must have wealth to leave; he or she must make a will; the will has to include a charitable bequest; the bequest may be conditional rather than absolute; and the bequest may be a cash amount or a residual share. In analysing the different steps, it is important that our new data cover the whole population leaving non-trivial estates. In contrast, much of the US literature based on estate tax data relates only to the upper tail of the distribution of estate size at death: for example the study by Joulfaian (2000) covers only 3 per cent of decedents. Moreover, in contrast to studies based on tax data, our data have fuller information about donor intentions available from the accompanying wills so that we observe all charitable bequests made, including those with conditions that may not be realised.

*Corresponding author: Peter Backus, Department of Economcis, University of Manchester, Arthur Lewis Building, Manchester, M13 9PL, UK. Email: peter.backus@,manchestera.ac.uk

This research was supported by ESRC project grant 'Giving to Development' (RES-155-25-0061), which formed part of the Non-Governmental Public Action programme. The project was conducted in conjunction with Cathy Pharoah and Sylke Schnepf whom we thank for discussion and suggestions. We are most grateful to Waterlow Legal and Regulatory Ltd. for providing access to the Smee \& Ford data that we use in the paper and to Smee \& Ford staff for answering our questions about them, but neither company is responsible for the ways in which we have interpreted the data. Waterlow Legal and Regulatory Ltd retain the copyright in the data. We thank Richard Radcliffe for help when we were planning the research, Jon Aldous of HMRC for clarifying statistics on inheritance tax and the distribution of wealth, David Joulfaian for information on intestacy in the US, and seminar participants at Bristol, UCL Institute for Education, LSE, Melbourne, and Oxford, and the editor and referees. 
Section 1 identifies the different steps and sets out the multi-stage framework. Section 2 describes our estates data. These are rich in terms of population coverage, but contain limited information about personal characteristics and the value of any charitable bequest. We therefore focus in Sections 3 and 4 on two main aspects. The first is the association of estate size with the probability of making a charitable bequest. Wealth is likely to affect differently the various steps in making a charitable bequest. For example, the propensity to make a will may be expected to rise with wealth and then level off, whereas the propensity to make a charitable bequest may rise more steadily. There is at present little empirical evidence about the patterns that prevail. For the UK, Wedgwood (1929) documented charitable bequests in wills published in The Times newspaper, but the nature of his sample raises obvious questions concerning the representativeness of the data. Dawson et al (2003) studied all estates passing through probate in Northern Ireland in 1937, 1967 and 1997, but did not consider the estate values. Aldous (2005) was based on just 911 estates. Even in the US, where the literature is far more extensive, the restriction of the great bulk of studies to tax data means that knowledge is limited to the variation in realised charitable bequests among just large estates.

One reason why charitable bequeathing may rise with wealth is progressive estate taxation combined with tax-deductibility of charitable bequests. Under the UK Inheritance Tax (IHT), the excess of an estate above a threshold ( $£ 300,000$ for most of the period in question) is subject to a 40 per cent marginal tax rate. The "price of giving" to charity (the amount by which inheritance of other beneficiaries is reduced) falls from 1 to 0.6 when the threshold is exceeded. The US literature on charitable bequests has been particularly concerned with identifying a price effect (e.g. Boskin, 1976, and Joulfaian, 2000). In Section 3 , we explore whether the propensity to bequeath to charity in Britain shows evidence of a sharp rise around the level of the tax-free threshold.

Our second focus is on the form of the charitable bequest, the subject of Section 4. The donor' $s$ intention to make a bequest does not necessarily mean that the charity benefits. Charitable bequests may be made subject to conditions - 30 per cent of all bequests in our data. Bequests may be a share of the residual estate after other legacies have been paid, and this residual may be zero. The literature based on estate tax data considers only realised intent: charitable bequests that result in a transfer to a charity. We are able to make use of the additional information from the accompanying wills to observe all charitable intent expressed in wills, whether realised or not. This feature of the data confers several advantages. For example, we can consider whether bequests become more certain in value as estate size rises, donors feeling more able to bequeath free of conditions and to bequeath specific amounts. 
We draw conclusions in Section 5. An on-line appendix considers the destination of bequests (see also Atkinson, Backus, and Micklewright, 2012). We examine the pattern of giving by cause, which has received little attention in the existing literature on charitable giving (e.g. see Andreoni, 2006).

\section{A Multi-stage framework for charitable bequeathing}

Making a charitable bequest is the result of several distinct steps. First, the person has to die with non-trivial assets. Second, the person has to make a will. Many people in the US and the UK die intestate (without making a will). In the US, 30 per cent of persons aged 70 or over report having no will (Francesconi, Pollak and Tabasso, 2015). In the UK, about 60 per cent of the adult population are in this position. ${ }^{1}$ Third, the will has to include a charity as a potential beneficiary. The word "potential" is important, since in many cases the charitable bequest is conditional. For example, the testator's spouse may have to die first for the charity to benefit. The fourth stage therefore distinguishes between absolute and conditional bequests to charities. Finally, the charitable bequest may take the form of a specific asset or a cash sum or it may be a share in the estate that remains after deduction of debts, tax, and other bequests.

The different stages are summarised in Figure 1. We focus on the $(0,1)$ nature of the decision at each stage. (The diagram includes a sixth stage, the choice of cause, considered in the on-line appendix.) The first theoretical models of the bequest decision (for example, Yaari, 1964) did not highlight the corner solution where bequests were chosen to be zero, but whether or not we are at a corner is important, as has been shown in the macro-economic literature, where Ricardian equivalence depends on there being "operative inter-generational transfers" (Blanchard and Fischer, 1989, ch.3). In the model proposed here, a person may be at a corner in making no bequests, or in making no charitable bequests.

Figure 1 here

The binary decision at each stage may be influenced by different considerations, as is the amount of the bequest. The first stage involves the leaving of a significant estate. Many people leave minimal, zero, or negative amounts at death. In Britain, in a typical recent year,

\footnotetext{
${ }^{1}$ The figure comes from an internet survey of 2,001 adults in 2013 (with results 'weighted to nationally representative criteria'). https://business.unbiased.co.uk/press-releases/willing-to-risk-it-more-than-half-of-alluk-adults-haven-t-made-a-will-7-10-2013
} 
just over half of all decedents do not leave property of a size and type to require a "grant of representation". The conditions under which a grant is required are described below. While these are not only based on the size of the estate, it seems reasonable to assume for the purposes of the present analysis that those estates not requiring a grant are not "significant".

Leaving a significant estate reflects both conscious decision-making and unpredictable events (see e.g. Kopczuk, 2007). We can make little use of a large literature on the former since for the full population of deaths we only observe age (usually) and gender. But the relative importance of the two sets of considerations is likely to change as a person ages, with "deliberate" bequests increasingly replacing "unintended" ones. Whether deliberate bequests increase with age depends on the life-cycle pattern of wealth-holding. It also depends on whether assets are used up by medical and care home expenses in the period prior to death.

The second stage is that of making a will. Here we can take account of both age (and gender) and the size of estate. For some, intestacy is a choice: the individual is content with the law of succession that applies to intestate estates, or at least with his or her perception of the law. Here intestacy is no different from the case where a will is made and no money is left to charity. But death intestate represents a "surprise" for decedents who intended to leave a charitable bequest - the zeros here hide unrealised charitable intent. Intestacy may be rare in the wealthy estates covered by the estate tax data in the US but can be expected to be more common in data like those we use that are not limited to high levels of wealth. ${ }^{2}$ Since making a will is not typically reversed, the proportion dying intestate can be expected to fall with age.

The third stage is that of making a charitable bequest. We expect the propensity to make such a bequest to rise with estate size, and we are interested in how rapidly it rises and whether it approaches an upper limit. As noted earlier, estate size affects the "price" of giving; with the Inheritance Tax in the UK, the effective price of a charitable bequest relative to a bequest to one's heirs falls from a factor of 1 to 0.6 when the tax-free threshold is exceeded. We therefore expect a jump at this estate size in the propensity to make charitable bequests.

The fourth stage involves conditionality. We emphasise this stage for two reasons. First, it is missed by studies based on estate tax returns. Charitable bequests that are conditional do not appear in data from this source where the conditions are not met; and no distinction can be drawn between bequests that were absolute and bequests that were conditional and the conditions were satisfied. Although the data measure correctly the amount

\footnotetext{
2 Of the 38,015 decedents with estate tax returns filed in the US in 2007 (when the threshold for filing was $\$ 2 \mathrm{~m}$ ), 1,617 had no wills (4.3 per cent). We are grateful to David Joulfaian for this information.
} 
of wealth transferred to charities (for estates above the tax threshold) they understate the full extent of the decedents' charitable intent. Second, the conditions are likely to depend on family circumstances. Models of the bequest decision emphasise that willingness to make a charitable bequest is likely to vary with an individual's marital status and dependents, and age: 'the conjecture, of course, is that married and younger persons have more, and more dependent, dependents: spouses and younger children' (Boskin, 1976: 46). Later authors in general conclude that the married give less at death to charity. IRS estates tax data in the US for 1995 show sharp differences in the propensity: 7 per cent of married decedents bequeath to charity, 25 per cent of the widowed, and 43 per cent of single (Havens et al 2006: 545). ${ }^{3}$ Gender has little impact in some studies (e.g. Boskin, 1976 and Joulfaian, 2000) while women are found to give less in others (e.g. Joulfaian, 1991). But these studies do not capture charitable bequests with conditions where the conditions were not met. When these bequests are included, the apparent impact of gender, marital status, and age may be reduced.

The fifth stage concerns the form of the charitable bequest - whether specific or a residual share. Where the total amount bequeathed is known with certainty when the decision is taken, then it does not matter whether the charity receives a specified $\mathrm{B}$ or $(\mathrm{B}+\mathrm{X})-\mathrm{X}$, where $\mathrm{X}$ are other bequests. But typically there is considerable a priori uncertainty about the size of the estate, the valuation of assets, and the tax regime at the time of death.

Finally, there is the allocation to different causes - the subject of the on-line appendix.

\subsection{Theoretical model}

The US literature has mostly modelled bequest behaviour as an extension of the standard theory of consumer choice. For instance, Boskin (1976) modelled utility as a function of own consumption, $\mathrm{C}$, other bequests, $\mathrm{X}$, and charitable bequests, $\mathrm{B}$ (where we have simplified by omitting lifetime transfers or charitable gifts). Utility, $U(C, X, B)$, is assumed to be maximised subject to a lifetime wealth constraint, such as

$$
\mathrm{C}+\mathrm{X}+\mathrm{B}=\mathrm{W}-\mathrm{T}(\mathrm{X})
$$

where $\mathrm{W}$ is lifetime wealth and $\mathrm{T}(\mathrm{X})$ the estate duty payable, which depends only on $\mathrm{X}$, charitable bequests being assumed exempt. The marginal tax rate is non-decreasing, ensuring a convex budget constraint. The model has been elaborated (e.g. Watson, 1984), but we stay close to the simple formulation so as to highlight the different stages of decision-making.

\footnotetext{
${ }^{3}$ Other dependents are sometimes found to have a negative effect too, although it should be noted that their presence is typically measured by the mention in the will of bequests to them, which hardly seems ideal.
} 
The model leaves out many important considerations. It does not provide a basis for analysing the decision to make a will, a stage in the bequest process that economists have neglected (McGranahan, 2006, is an exception). Without introducing transaction costs, we cannot explain why people die intestate, unless they are content with the law concerning the distribution of intestate estates. ${ }^{4}$ (There may be an indirect explanation via the second and subsequent stage decisions.) The model is one of individual behaviour whereas conditionality of bequests may be the result of a joint decision of husband and wife (allowing for the survivor to retain all the couple's assets until the second death). It is the first and third stages of our framework - the dying with significant assets and the leaving of a charitable bequest where the model is potentially informative. The corner conditions for utility maximisation are

$$
\mathrm{U}_{\mathrm{x}} \leq \lambda\left(1+\mathrm{T}^{\prime}\right) \text { and } \mathrm{X}=0 ; \text { and } \mathrm{U}_{\mathrm{B}} \leq \lambda \text { and } \mathrm{B}=0
$$

where $\lambda$ is the marginal utility of own consumption ( $\mathrm{C}$ is assumed strictly positive). It should be noted that where there is a tax-exempt range the first condition does not involve the marginal tax rate. Such a progressive estate tax plays therefore no role in the first-stage decision (given the assumption of a convex budget constraint). It is assumed that there is a level of lifetime wealth so low that no one leaves any bequests. Where $\mathrm{X}=\mathrm{B}=0$, the value of $\lambda$ is $U_{c}(W, 0,0)$, which is assumed to be a declining function of $W$. If we further assume that $\mathrm{U}_{\mathrm{X}}(\mathrm{W}, 0,0)$ and $\mathrm{U}_{\mathrm{B}}(\mathrm{W}, 0,0)$ are increasing functions of $\mathrm{W}$, then as we consider higher values of $\mathrm{W}$, there comes a point where people begin to leave a positive estate. The level of wealth at which this happens, and whether X or B becomes positive first, depends on preferences.

The simplest case is people who have no other heirs and set $\mathrm{X}=0$. Assume that there is a single preference parameter, $\gamma$, measuring the weight given to charitable bequests relative to own consumption, with a survival function $\mathrm{F}\{\gamma\}$ (so that a proportion $\mathrm{F}\{\gamma\}$ have values in excess of $\gamma$ ). For given wealth level, $\mathrm{W}$, there is a proportion $\mathrm{F}\left\{\gamma^{*}(\mathrm{~W})\right\}$ of the population who make charitable bequests, where this increases with $\mathrm{W}$. The estate tax has no effect.

Where people have heirs, we must consider the weight given to charitable bequests, not only relative to own consumption, but also relative to bequests to heirs. There are several possibilities. Those who give more weight to charitable bequests at first follow a pattern similar to that described above, and then, at a higher $\mathrm{W}$, begin to set $\mathrm{X}$ positive. Those who give more weight to their heirs first set $\mathrm{X}$ positive and then, at a higher $\mathrm{W}$, begin to make

\footnotetext{
${ }^{4}$ The approach assumes that individuals have complete freedom to dispose of their wealth at death. This is broadly the case in the England and Wales (the situation in Scotland differs) although legislation can impede this freedom ex-post and threaten charitable bequests if the deceased is deemed to have unreasonably failed to make sufficient provision for his or her family (Hannah and McGregor-Lowndes 2008). Testamentary freedom is more limited in other countries with legal systems that embody the Napoleonic code and this may encourage intestacy.
} 
positive charitable bequests. From this we see that the proportion making charitable bequests is an increasing function of lifetime wealth, the form of the function depending both on the functional form of utility $U$ and on the distribution of taste parameters.

The position is further complicated by the progressive estate tax. In the simplest case, as in the UK, there is a single tax rate, $t$, above the tax threshold, $\mathrm{T}_{0}$. Once the threshold is reached, the first order condition for determining the choice of $X$ involves $\lambda$ multiplied by (1$\mathrm{t})$. This means that there is a range of $\mathrm{W}$ where the utility-maximising person keeps the value of the bequest to their heirs equal to the threshold, with increases in $\mathrm{W}$ being concentrated on $C$ and $B$. Where $B=0$, this means that $U_{B} / \lambda$ is rising faster than it otherwise would, and hence the proportion making charitable bequests is also rising faster. $\mathrm{X}$ begins to increase once again when $\mathrm{W}$ has reached a level such that $U_{\mathrm{x}}=\lambda(1-\mathrm{t})$ is consistent with $\mathrm{X}$ greater than $\mathrm{T}_{0}$, and $\mathrm{U}_{\mathrm{B}} / \lambda$ reverts to its previous rate of increase. There may therefore be a range around the tax threshold where the proportion making charitable bequests rises more sharply.

The implications for our empirical analysis are that the propensity to leave an estate is an increasing function of $\mathrm{W}$ and is not a function of the tax, where there is a positive exemption level. The propensity to make a charitable bequest rises with $\mathrm{W}$, and is influenced by the tax system in the way just described. It has to be remembered however that we do not observe $\mathrm{W}$ in practice; we observe W-C.

The model just described underlies much empirical work but it has severe limitations. Utility derived from bequests - whether charitable or to relatives - is assumed to be of the "pure warm-glow" variety (Andreoni, 1990). The donor is simply concerned with the sum left. No account is taken of heirs' circumstances. There is no place for conditionality of either $\mathrm{X}$ or $\mathrm{B}$. In the case of charitable bequests, no account is taken of the likely benefits from the use of the funds. The theory takes no account of the "public good" motive for giving (Becker, 1974), vital if we are to examine giving by cause. A second major objection is that the model assumes a degree of foresight that is simply unrealistic in most cases. Wills are often drawn up many years before death and are only occasionally reviewed: "10, 20 or 30 years may elapse between a testator making a will and his death, during which time his circumstances have changed beyond recognition. He may no longer own a particular item of property that was specifically bequeathed. He may be significantly better off. Some of the beneficiaries may already be dead" (Dawson et al, 2003: 35-6). Their research for Northern Ireland found that over a quarter of wills were made more than 10 years prior to death (2003: 52).

In view of these limitations, the model provides a starting point, but no more, for our empirical analysis. 


\section{Data on estates and charitable bequests in Great Britain}

Wedgwood (1929) took his data from the listing of estates in The Times. The source of these newspaper listings, which continue today, are the reports provided by a commercial company, Smee \& Ford Ltd., which informs those charities that subscribe to its legacy notification service of the bequests that they may receive. To do this, Smee \& Ford read all grants of representation and accompanying wills. They also read grants for persons who die intestate. We make use of exactly the same source. Our data refer to 253,706 estates in Britain processed by Smee \& Ford during the 12 months August 2007 to July $2008 .^{5}$

Our data relate to all estates in Britain (but not Northern Ireland) that go through probate: i.e. estates for which a 'grant of representation' is issued. A grant of representation is not required if all assets were held jointly with another person e.g. a spouse (since in this case the assets pass automatically to the surviving joint owner) and may not be required if the estate is small in value. The law permits certain assets up to a value of $£ 5,000$, such as a bank account, to be dealt with without production of a grant of representation, although estates smaller than $£ 5,000$ may nevertheless pass through probate if the executors so choose and have to if the assets they contain are not all within the permitted group.

Estates not requiring a grant of representation are not necessarily small. Joint property, such as a house, may have a substantial value. The threshold for the transfer of assets applies per asset rather than to the total estate so in principle an estate of several accounts of under $£ 5,000$ each could be administered without a grant. But there are good reasons for treating the non-requirement for probate as an indicator that there is not significant wealth available for charitable bequests. If the only property is joint property, then it is unlikely to be available for charitable donation. ${ }^{6}$ We have been told by Her Majesty's Revenue \& Customs (HMRC) that the 'small estate' category probably accounts for the large majority of estates that do not go through probate. ${ }^{7}$ We therefore treat the category of estates not requiring probate as equivalent to 'insignificant wealth' for the purposes of our investigation of charitable bequests. For the same reason we drop estates of net value less than $£ 5,000$.

\footnotetext{
${ }^{5}$ For a fuller account of the data, see Atkinson, Backus and Micklewright (2009, 2012).

${ }^{6}$ If owners are 'joint tenants', the house must pass to the surviving owner when one of them dies irrespective of the terms of their wills. Only if the couple are 'tenants in common' can they dispose of their share in their wills as they see fit. Joint tenancy is more usual in Britain than tenancy in common (see e.g. Dawson et al 2003: 40). ${ }^{7}$ HMRC noted that an investigation of the estates of widows and widowers above the inheritance tax threshold showed that probate had not been sought for only about 4 to 8 per cent of the late spouses' estates - in the great majority of cases, the estate had passed through probate on the first death. No information is available on the number or value of estates that pass between spouses which do not require a grant of representation.
} 
For each estate, we know gender, date of death, whether the decedent was testate, number of charitable bequests, form that each bequest takes and the charitable cause concerned, and value of the estate. In England and Wales, age of the deceased is recorded for 90 per cent of estates below the IHT threshold and for almost none above it. Age is recorded for all Scottish estates. Both gross and net estate values are recorded. Net value is gross value less outstanding debts, including funeral expenses and any mortgage loan on a property. It is these 'net' values that we analyse: the values of the estate before any inheritance tax is deducted. Estate value is missing in only 0.5 per cent of cases. About 80 per cent of our sample died in the tax-year April 2007 to April 2008 when the tax-free allowance for IHT was $£ 300,000 .^{8}$

We drop 8,239 estates with date of death before 1 January 2005 and another 4,555 estates below $£ 5,000$ in value. This leaves 240,912 estates. Table 1 shows summary statistics for our sample. Mean age at death, 79 years, is 3 years below the median. Estate value shows strong positive skew: median $£ 146,000$, mean $£ 221,000$, and a top percentile of nearly $£ 1.4 \mathrm{~m}$. If we take $£ 300,000$ as the IHT threshold, then only 18 per cent of the estates are above this level. Broadly speaking, it is only for these estates, with a median value of $£ 434,000$ - three times the value of the median in our whole sample - where the IHT return accompanying a request for probate would contain information about charitable bequests. The IHT return made for an estate below the threshold is on a simpler form that does not list bequests.

Table 1 here

Where the will contains a charitable bequest, the type of each bequest is coded into one of three categories: (i) 'effects' or items (e.g. clothes, jewellery), (ii) 'pecuniary', i.e. a sum of money, financial assets (e.g. shares) or real property (houses and land), and (iii) a residuary share, i.e. a share of the value of the estate that remains after all pecuniary legacies and legacies of specific items to heirs (and other charities) have been paid. Importantly, both pecuniary and residuary share bequests to charity are further distinguished into those that are unconditional ('absolute') and those that are conditional e.g. that only take effect if the spouse predeceases. ('Effects' bequests are all treated as absolute.) This provides for a more complete measurement of donors' charitable intentions than do estate tax data as we observe both

\footnotetext{
${ }^{8}$ The last death was on June 18, 2008.
} 
realised and unrealised intent. In total, the dataset contains information on 107,639 charitable bequests, of which 30 per cent have conditions attached, made by 33,487 decedents.

The attractions of the data are that they relate to the population of estates passing through probate, the value of the estate is almost always coded, testate estates can be identified, and the presence of all charitable bequests are recorded together with their type and the causes to which they are made. The sample size allows estimation with considerable precision of how charitable bequests vary with wealth at death, not only at the modest asset levels possessed by many people when they die but also at much higher estate values.

But the data have two major limitations. First, we only rarely observe marital status, a variable found to be important by Aldous (2005). Nor do we observe other details about the individual's family, e.g. children or other surviving relatives. ${ }^{9}$ These characteristics may enter in two different ways. To the extent that they influence charitable intentions, we are missing an important determinant; but to the extent that they work via the conditionality of bequests, their omission is less serious for our analysis of charitable intent. Second, the value of any charitable bequest is recorded only if the bequest is a specific sum of money, is made unconditionally, and was made to a Smee \& Ford client (or a few other charities). This means that we observe the presence but not the value of the bequests of specific items or residuary shares (we observe the value for only 6 per cent of all bequests). (Nor can we calculate the latter since we do not observe the size of any legacies made to the decedent's heirs.) We know from other sources that the average charitable legacy from residuary bequests is much larger than the average cash legacy (Radcliffe 2002: 61). This means that we focus in what follows on the propensity to leave a charitable bequest rather than the amount. ${ }^{10}$

\section{Wealth and charitable bequeathing}

\subsection{Leaving significant wealth}

The first stage concerns those who left significant wealth at death, defined here as leaving an estate that required a grant of representation and of value $£ 5,000$ or more. We measure the probability of leaving significant wealth by comparing the observations in our sample with the national population data on deaths by age and gender. But our sample of

\footnotetext{
${ }^{9}$ Both types of information are recorded on the IHT return that must be made for each estate passing through probate. These returns were drawn on in the construction of the dataset used by Aldous but they are not made available to Smee \& Ford. (Where marital status is recorded, the information comes from the will.)

${ }^{10}$ In Atkinson, Backus and Micklewright (2009, Appendix) we provide some limited analysis of the amounts bequeathed where these are known.
} 
estates processed over 12 months (August 2007 to July 2008) relates to deaths occurring over a much longer period, which even with trimming extends from 1 January 2005 to 18 June 2008. Given the regularity of the death rate in Britain over this period, we can expect that the number of estates going through probate in a 12 month period approximates well the number of deaths requiring probate in a 12 month period. Our estimates are approximate in that we compare the observed data with the 560,038 deaths in Great Britain in the calendar year 2007.

The top half of Figure 2 shows estimates separately for Scotland, where we observe age at death for all estates, and England and Wales, where age at death is missing in a quarter of cases. (We exclude the 3 per cent of deaths occurring below age 40.) The figures for England and Wales are thus under-estimated as the denominators used to calculate the probabilities are based on complete population data. It is therefore re-assuring to see a gap between the two series that is roughly constant, suggesting that the missing data result in little bias in the picture obtained for England and Wales of the change in the probability with age. ${ }^{11}$

The probability of leaving significant wealth rises sharply with age. In England and Wales, the percentage rises by over 15 points between age 40-44 and age 95-99. The bottom half of Figure 2 shows that the rise is at first similar for men and women before that for men falls behind, only to rise sharply at later ages (the figures refer to England and Wales only). ${ }^{12}$

Figure 2 here

\subsection{Making a will}

Of the 240,912 estates in our data, 36,014 (15 per cent) are where people died intestate. If the 57 per cent of deaths not covered by our data were all intestate, the overall rate of intestacy would be 63 per cent. This figure for Britain is below the 77 per cent given by Dawson et al (2003: 50) for Northern Ireland in 1997, although it is probably an over-estimate as some decedents not in our data have made wills but no probate was required.

Who made wills? Table 2 column 3 shows the percentages testate by estate range. (We show three different stages in the table; we return below to the other columns.) The probability of dying testate, conditional on possessing significant wealth, rises from under 75 per cent in the lowest ranges to 90 per cent plus in the top third of the distribution. The

\footnotetext{
${ }^{11}$ The estimates for Scotland for ages 40-44 and 45-49 are based on denominators of about 1,000 deaths only and the estimate for age $100+$ on just 350 deaths.

${ }^{12}$ It should be noted that the age pattern is different from that of median wealth among the living population indicated by the Wealth and Assets Survey carried out in 2006/8, which peaks at age 55-64 (Office for National Statistics, 2009: 11).
} 
relationship is graphed in Figure 3. (As with Table 2, we show all stages 2 to 4 of our multistage framework.) The vertical line shows the median, $£ 146,000$. The bottom part of the graph focuses on estates below $£ 500,000$. The percentage making a will rises sharply from about 50 per cent below $£ 10,000$ to nearly 80 per cent for estates around the bottom quartile, $£ 60,000$, then rises more slowly to 90 per cent for estates of around $£ 200,000$, a level not far short of the top quartile. The rise - but not necessarily its pattern - is hardly surprising. What is remarkable is that some people die leaving estates of over $£ 1$ million without making a will. The figure of 3.3 per cent may be compared with that of 4.3 per cent among deaths resulting in estate tax returns in the US in 2007 when the threshold for filing was $\$ 2 \mathrm{~m}^{13}$

Table 2 here

Figure 3 here

How does testacy change with age? And are men more likely to die intestate than women? Among people dying at age 50-54, as many as 52 per cent are intestate, reflecting the 'surprise' that death may represent at that age. But by age 85-90, only 10 per cent of decedents are intestate. The rise in testacy with age and the fact that men on average die at a younger age (see Table 1) helps explain why the overall testacy rate is lower for men (82 per cent) than for women ( 88 per cent). But Figure 4 shows there are still gender differences within age groups. (The graphs relate to estates in England and Wales for which age at death is recorded.) For those aged 55-64, the percentage dying intestate is 10 points higher for men. We cannot control for marital status but with this proviso it does appear that men dying at below average ages are less likely to have made a will than women of the same age.

Figure 4 here

\subsection{Making a charitable bequest}

Having made a will, the next step is whether to include a charitable bequest (with or without conditions). Overall, 16 per cent of testate estates did so. Given the testacy rate of 85 per cent and our calculation that the data cover some 43 per cent of all deaths, this implies that 6 per cent of deaths in Britain in 2007 resulted in a charitable bequest. This compares well

\footnotetext{
${ }^{13}$ See footnote 2.
} 
with the estimate of about 5 per cent from Radcliffe (2002). (It should be borne in mind that some estates that do not pass through probate also contain bequests to charities.)

How does the propensity to bequeath to charity vary with size of estate? Table 2 (column 4) shows that there is indeed substantial variation. For the smallest estates, 1 in 10 have a charitable bequest; for those over $£ 1$ million it is more than 4 in 10 . The rise is not smooth. The propensity to bequeath to charity rises little through the bottom half of the distribution, something seen most clearly in the lower part of Figure 3. The rise is then particularly noticeable around the IHT threshold, $£ 300,000$ for most estates in our sample. For the range from $£ 250,000$ to $£ 299,999$, the percentage is 17 per cent; by $£ 500,000$ to $£ 999,999$, it has virtually doubled. We return to this below. As may be seen from Figure 3, the increase in the proportion continues above $£ 1$ million: a half of all testate estates of $£ 3$ m or more contain charitable bequests. ${ }^{14}$ The $£ 1 \mathrm{~m}$ level is similar in US dollar terms to the threshold for estate tax filing in the US in 2004-5. Were we limited to data with that minimum value for estate size we would miss most of the variation in the propensity to bequeath to charity. The percentages of large estates containing a charitable bequest in our data may be compared with those in the US shown by IRS data. In 2004, 17 per cent of estates with less than \$2 m in gross value had a charitable bequest, rising to 44 per cent in estates with $\$ 20 \mathrm{~m}$ or more (Raub 2008: 126). The US figures are lower than those for Britain but they refer only to bequests that were realised. Our data include also conditional bequests where the conditions were not met.

It is a common belief that women are more likely to give to charity than men and this is the case for inter-vivos giving in the UK, with women 1.2-1.3 times more likely to report giving when asked about donations in the previous month (Micklewright and Schnepf, 2009). Our data show this sort of differential is repeated in giving at death: the proportion of testate estates containing charitable bequests is 14 per cent for men and 18 per cent for women. The propensity to bequeath to charity is higher for women within all but the youngest age group see the middle panel of Figure 4. It should be noted that our figures include both absolute and potential conditional bequests; we are not restricting attention only to bequests that were realised. So the gender differential is not attributable to men being more likely to have a surviving spouse (and hence for charitable bequests not to be activated). It is notable that the percentages bequeathing to charity do not change much with age.

\footnotetext{
${ }^{14}$ The two standard error confidence intervals for the percentages with a charitable bequest in the top two ranges of estate size are about $+/-4$ points.
} 


\subsection{Inheritance Tax}

The model in Section 1 suggests a jump in the proportion of decedents making a charitable bequest when the estate reaches the IHT threshold, $£ 300,000$ for most of our sample. The percentage rose from 17 per cent to 33 per cent between estates in the range $£ 250,000$ to $£ 299,999$ and $£ 500,000$ to $£ 999,999$. But it is unclear how much of the increase is due to the rise in estate value and how much to any IHT effect. Disentangling the two is complicated as the impact of IHT is unlikely to appear as a discrete jump; instead we expect the shift in the propensity to take place over a range of wealth for two reasons.

First, the point at which the tax applies for a particular estate may differ from the value of the IHT threshold. Assets left to a surviving spouse or civil partner are free of tax by law, and do not use up the tax-free allowance. And from November 2007 - within the period covered by our data - the executors of an estate of a widow or widower could claim any IHT allowance unused by the former spouse as a result of having left assets to their surviving partner. The unused allowance is granted at the current rate, doubling the value of the tax-free threshold for many widows and widowers. Even before this change in the law, many estates larger than $£ 300,000$ in value were free of tax. HMRC figures for persons dying in 2005-6 show that fewer than two-thirds of estates above this size were taxed, although this is after taking into account the reduction in tax liability due to any charitable bequests (IHT statistics, Table 12.3). ${ }^{15}$ In some cases tax is due even if the estate is below the normal threshold: IHT takes account of gifts made in the 7 years before death. We do not observe marital status at death, bequests made to a surviving partner, bequests made by a former partner, or any gifts in the years before death - all information needed to calculate the tax liability for an estate.

Second, charitable bequests are often determined some time before death. The testator has to form a view about likely future estate value and the future tax regime. Both may change substantially. The former depends on housing and stock markets and on unplanned consumption in the form of medical or nursing fees (as noted earlier, we observe W-C and not W). Dramatic swings in US estate tax illustrate changes in the latter: \$2 m threshold in 2006-8, $\$ 3.5 \mathrm{~m}$ in 2009, tax abolition in 2010, and re-introduction with a \$5m threshold in 2011.

In Figure $5 \mathrm{a}$ we probe more carefully the change in the propensity to bequeath to charity, conditional on testacy, around the standard IHT threshold of $£ 300,000$. We focus on estates of size $£ 200,000$ to $£ 399,999$ (of which there are 57,496 in our data) and use local polynomial smoothing to allow the shape of the relationship between estate size and the

\footnotetext{
${ }^{15} \mathrm{http}: / \mathrm{hmrc} . g o v \cdot u k /$ statistics/inheritance.htm\#5
} 
bequest propensity to be traced out in a flexible way. The data suggest a steepening in the relationship in the interval $£ 275,000$ to $£ 325,000$, consistent with the prediction of our theoretical model. We then test for a change in the marginal effect of estate size by estimating a linear probability model (OLS) for the propensity to bequeath to charity, specifying this to be a piecewise linear function of estate size (using the same sub-sample). We place the knots at $£ 275,000$ and $£ 325,000$. The slopes of the function below the lower knot and above the upper knot do not statistically differ from one another ( $p$-value $=0.49$, we use heteroscedastic-robust standard errors). The slope between the knots is about twice as large as that elsewhere. We then constrain the slopes below $£ 275,000$ and above $£ 325,000$ to be the same. Assume that the steepening of the slope within this range is entirely due to the reduction in price produced by the inheritance tax. The constrained model's predicted probability of a charitable bequest at $£ 325,000$ is 2.3 percentage points higher than it would be in the absence of tax incentive. ${ }^{16}$

The piece-wise linear model facilitates the estimate just made. But its discrete changes in slope may not be appropriate given the "fuzzy" nature of the effect that we are investigating. Cubic polynomial functions allow more generously for non-linearities in the data and cubic splines can be made smooth by forcing the first and second derivatives to agree at the knots (Royston and Sauerbrei, 2007). We now estimate a linear probability model of this form with knots at $£ 275,000$ and $£ 325,000$, this time widening the estimation range up to $£ 600,000$. This allows the charitable bequest decision to be a non-linear, continuously differentiable function of estate size. Figure $5 \mathrm{~b}$ plots the resulting estimates of the marginal effect of estate size against the size of the estate. The graph again illustrates the significant increase in the marginal effect around the IHT threshold relative to its value at both higher and lower estate values. The marginal effect increases as the IHT threshold is approached and falls beyond it, eventually returning to parity with that for smaller estates. ${ }^{17}$ We make no claim to have firmly identified a causal effect, but the results are consistent with the IHT leading to an increase in charitable intent as predicted by our theoretical model. ${ }^{18}$

\footnotetext{
${ }^{16}$ This implies a price elasticity of the probability of bequeathing to charity of about -0.3 . (The price falls by 40 per cent, from 1.0 to 0.6 , and the probability of giving rises by 11.9 per cent, from 0.191 - had there been no steepening in the relationship with estate size - to 0.214.)

${ }^{17}$ We estimated this model using various different permutations of the number of knots, their location and the range of estate sizes used in estimation. We also estimated the model using the knot placement rule suggested in Harrell (2001). While the precision of the estimated marginal effects varied (both positively and negatively), the overall shape of the pattern of change across estate size is very robust.

${ }^{18}$ Recall that we observe charitable intent, not only the realisation of that intent. Were we to observe only the latter we would need to control for characteristics that may determine the satisfaction of conditions in wills (e.g. presence of children, marital status). Concerns about possible omitted variable bias in our parametric estimation are therefore mitigated by the fact that we observe all charitable bequests. We also estimated the model
} 
Figures $5 \mathrm{a}$ and $5 \mathrm{~b}$ here

Our theoretical model is silent on the impact of the tax on making a will and on the form of a charitable bequest. Estimating linear probability models with a restricted cubic spline, we find no evidence of a change in marginal effect for these stages of the sort shown in Figure 5b.

\section{The form of the charitable bequest}

For the charity to be sure of receiving a bequest it has to be absolute (and the estate to have sufficient assets). 30 per cent of all charitable bequests in our data had conditions attached (we do not know if they are met). Conditional bequeathing is an important feature of charitable giving at death. Of all testators leaving a charitable bequest, 73 per cent left an absolute bequest (they may also have made conditional bequests). The figure is about 60 per cent for smaller estates, rising to around 85 per cent for estates of over $£ 1 \mathrm{~m}$ - see Table 2 and Figure 3. (The fall at over $£ 3 \mathrm{~m}$ is not statistically significant.) Greater wealth at death is associated with more absolute charitable bequests. It is this rise in absolute bequeathing that drives the increase in the propensity to bequeath to charity with estate size. The top half of Figure 6 shows how the form varies with estate size. (Since estates may contain both forms, the sum of the two estimates at any estate value exceeds the figure for the percentage of estates containing either form.) The percentage of charitable testators leaving an absolute bequest also rises with age at death - see Figure 4. It is not perhaps surprising that men are less likely, for reasons discussed, to make an absolute bequest: 64 per cent, compared to 78 per cent for women. The gap opens up above the age of 65 and is substantial until the late $90 \mathrm{~s}$.

Figure 6 here

The other choice testators must make is whether to leave a specific amount (or item) to charity - a 'pecuniary' bequest - or a residuary share of the estate. The importance of this distinction is that: "the debts owing ... together with the expenses of administration will firstly be borne by the residue, then out of pecuniary legacies and only as a last resort out of legacies of specific assets. ... As a result the net residuary estate may be significantly less valuable ... On the other hand, any unexpected increases in the value of the residue could be to the advantage of the residuary beneficiaries" (Dawson et al, 2003: 165). For the charities

separately for men and women. The pattern of a rise and fall in the marginal effect is present in both cases, the change being somewhat larger for women. 
that are the potential recipients, residual bequests involve greater uncertainty. In particular, they are more vulnerable to falls in asset prices. But for the testator, bequeathing in this form provides insurance against uncertainty. The bottom half of Figure 6 reflects the decline in need for this insurance as estate size rises: the propensity to bequeath a specific sum (or item) to charity rises more quickly than the propensity to leave a residuary share.

Taking the two dimensions of form of bequest together - absolute vs. conditional and pecuniary vs. residuary - the nature of charitable bequeathing changes a great deal across the distribution of estate size. The proportion of all charitable bequests that are both absolute and pecuniary rises from 30 per cent in estates of $£ 10,000$ to $£ 59,000$ to $55-60$ per cent in estates of over $£ 1 \mathrm{~m}$ (Atkinson, Backus and Micklewright, 2009, Table 5). And the bequests that are both conditional and residuary fall from about 30-35 per cent of the total to 10-13 per cent.

As estate size rises, testators are therefore more certain in their form of bequeathing to charity. This increase in certainty would appear to benefit charities, but we should note that we have not been able to analyse the amounts concerned. An uncertain residuary share of a large estate may yield a greater expected sum for a charity than a certain pecuniary bequest. For the subset of pecuniary bequests for which we have information on their value, the median amount bequeathed is only $£ 1,000$ (Atkinson, Backus and Micklewright, 2009, Table A1). ${ }^{19}$ As we noted earlier, other sources indicate that the average residuary bequest to charity is indeed much larger than the average pecuniary bequest.

\section{Conclusions}

Our main findings are the following:

- To understand giving to charitable causes, it is necessary to consider a multi-stage process: leaving significant wealth at death, making a will, including a charitable bequest, the conditions under which a bequest materialises, and the form in which it is made;

- The different stages in the decision process are influenced differently by the variables that we have considered: age, gender, and our particular focus, estate size;

\footnotetext{
${ }^{19}$ Moreover, the evidence suggests that pecuniary bequests are unlikely to have been indexed for inflation from the date at which the will was made (Dawson et al. 2003: 168, Atkinson, Backus and Micklewright, 2009: 33).
} 
- The proportion of decedents leaving significant wealth rises steadily with age at death; from age 65 to 90 , it is higher for women;

- The percentage making a will rises with age, is higher for women, and at first rises sharply with estate size - although it is still only 90 per cent for estates of around $£ 200,000$, a level not far short of the top quartile of the distribution of wealth at death;

- 16 per cent of wills included a charitable bequest; the figure rises substantially with estate size - from 10 per cent for the smallest estates in our data to 50 per cent for the largest of over $£ 3 \mathrm{~m}$; there seems a sharper increase around the Inheritance Tax threshold, consistent with a theoretical model of the tax's impact, of about 2 percentage points;

- Higher wealth at death is associated with testators being more likely to leave an absolute bequest, free of conditions, and more likely to leave a bequest of a specific amount to charity, as opposed to a bequest of a residual share of the estate; 30 per cent of all charitable bequests have conditions attached. It is the rise in absolute bequeathing that accounts for the rise in the bequest propensity with estate size.

Many of our results would be unobtainable using datasets of the type used in much of the existing literature. Our data have provided fuller information about donor intentions and have not been restricted to the small fraction of the population covered by estate tax returns for large estates that detail any realised charitable bequests. 
Nuffield College, Oxford, and London School of Economics

University of Manchester

University College London

Additional Supporting Information may be found in the online version of this article:

Appendix A: Bequests by cause

\section{References}

Aldous, J. (2005). 'Analysis of legacies to charities - destination at death sample', HMRC, unpublished.

Andreoni, J (1990). 'Impure Altruism and Donations to Public Goods: A Theory of WarmGlow Giving', THE ECONOMIC JOURNAL, vol. 100(401), pp. 464-77.

Andreoni J (2006) 'Philanthropy' in S-C Kolm and J M Ythier (eds.) Handbook of the Economics of Giving, Altruism and Reciprocity. Volume 2. Amsterdam: North-Holland.

Atkinson, A.B., Backus, P.G. and Micklewright, J. (2009). 'Charitable bequests and wealth at death in Great Britain', Working Paper A09/03, Southampton Statistical Sciences Research Institute.

Atkinson, A.B., Backus, P.G. and Micklewright, J. (2012). 'Charitable bequests and wealth at death', Discussion Paper 7014, IZA, Bonn.

Becker, G. (1974). 'A Theory of Social Interaction', The Journal of Political Economy, vol. 82(6), pp. 1063-93.

Blanchard, O.J. and Fischer, S. (1989). Lectures on Macroeconomics, Cambridge, Mass.: MIT Press.

Boskin, M.J. (1976). 'Estate taxation and charitable bequests', Journal of Public Economics, vol. 5(1), pp. 27-56.

Charities Aid Foundation (2004). Charity Trends 2004: 25 th Anniversary Edition, CAF and CaritasData.

Dawson, N., Grattan, S., Lundy, L., Glenn, R. and Cran, G. (2003). Dying to Give? Trends in Charitable Giving by Will, London: The Stationery Office.

Francesconi, M., Pollak, R., and Tabasso, D. (2015). 'Unequal bequests' Geneva School of Economics and Management Working Paper 15-01-3

Hannah, F. and McGregor-Lowndes, M. (2008). 'From testamentary freedom to testamentary duty: Finding the balance', Working Paper No. CPNS 42, Australian Centre for Philanthropy and Nonprofit Studies. Brisbane: Queensland University of Technology. 
Harrell, F.E. (2001). Regression Modeling Strategies, With Applications to Linear Models, Logistic Regression, and Survival Analysis, New York: Springer.

Havens, J.J., O’Herlihy, M.A. and Schervish, P.G. (2006). 'Charitable Giving: How Much, by Whom, to What, and How?' in W P Powell and R Steinberg (eds.), The Non-Profit Sector: A Research Handbook, 2nd ed., New Haven and London: Yale University Press.

Joulfaian, D. (1991). 'Charitable bequests and estate taxes', National Tax Journal, vol. 44(2), pp. 169-80.

Joulfaian, D. (2000). 'Estate taxes and charitable bequests by the wealthy', National Tax Journal, vol. 53(3), pp. 743-63.

Kopczuk, W. (2007). 'Bequest and Tax Planning: Evidence from Estate Tax Returns,' The Quarterly Journal of Economics, vol. 122(4), pp. 1801-54.

McGranahan, L. (2006) 'Will writing and bequest motives: early $20^{\text {th }}$ century Irish evidence', WP 2006-18, Federal Reserve Bank of Chicago.

Micklewright, J. and Schnepf, S. (2009). 'Who gives charitable donations for overseas development?', Journal of Social Policy, vol. 38(2), pp. 317-41.

Office for National Statistics (2008) Mortality statistics. Deaths registered in 2007, London: Office for National Statistics.

Office for National Statistics (2009), Wealth in Great Britain, London: Office for National Statistics.

Radcliffe, R. (2002). 'Where Now for Legacy Fundraising?', in C Walker and C Pharaoh (eds), A Lot of Give, Hodder and Stoughton.

Raub, B. (2007). 'Recent Changes in the Estate Tax Exemption Level and Filing Population', Statistics of Income Bulletin, Summer, pp. 114-17.

Raub, B. (2008). 'Federal Estate Tax Returns Filed for 2004 Decedents' Statistics of Income Bulletin, Spring, pp. 115-95.

Royston, P. and Sauerbrei, W. (2007). 'Multivariable modelling with cubic regression splines: A principled approach', The Stata Journal, vol.7(1), pp. 45-70.

Silverman, B.W. (1986). Density Estimation. London: Chapman and Hall.

Watson, H. (1984). 'A note on the effects of taxation on charitable giving over the life cycle and beyond', Quarterly Journal of Economics, vol. 99(3), pp. 639-47.

Wedgwood, J. (1929). The Economics of Inheritance, London: Routledge.

Yaari, M.E. (1964). 'On the consumer's lifetime allocation process', International Economic Review, vol. 5(3), pp. 304-17. 
Table 1. Distribution of Age at Death and of Estate Size

\begin{tabular}{lrrrrrr} 
& \multicolumn{3}{c}{ Age at death } & \multicolumn{3}{c}{ Estate size $(£ 000$ s): } \\
Summary statistic & All & Men & Women & All & Men & Women \\
\hline mean & 79 & 76 & 82 & 221 & 232 & 213 \\
$10^{\text {th }}$ percentile & 61 & 58 & 65 & 22 & 21 & 22 \\
$25^{\text {th }}$ percentile & 73 & 69 & 76 & 59 & 53 & 64 \\
median & 82 & 79 & 84 & 146 & 141 & 150 \\
$75^{\text {th }}$ percentile & 88 & 85 & 90 & 255 & 256 & 254 \\
$90^{\text {th }}$ percentile & 93 & 90 & 94 & 404 & 416 & 396 \\
$99^{\text {th }}$ percentile & 99 & 97 & 100 & 1,346 & 1,475 & 1,238
\end{tabular}

Notes: Sample size is 240,912 observations. The 'All' figures for estate size include 1,722 observations for which gender is missing; of the remainder, $46 \%$ are men. Age at death is missing for $23 \%$ of estates. 
Table 2. Testacy and Charitable Bequeathing by Estate Size

\begin{tabular}{lrrrr}
\hline \multicolumn{1}{c}{$(1)$} & $(2)$ & $(3)$ & $(4)$ & $(5)$ \\
$\begin{array}{l}\text { Estate range } \\
\text { (minimum } \\
\text { value, £k or } \\
£ \text { m) }\end{array}$ & $\begin{array}{r}\text { number of } \\
\text { estates }\end{array}$ & $\begin{array}{r}\% \\
\text { of estates } \\
\text { that are testate }\end{array}$ & $\begin{array}{r}\text { of testate estates } \\
\text { with a charitable } \\
\text { bequest }\end{array}$ & $\begin{array}{r}\text { of charitable } \\
\text { estates with an } \\
\text { absolute bequest }\end{array}$ \\
\hline 5 & & 52.9 & 10.7 & 57.3 \\
10 & 5,806 & 71.8 & 12.5 & 65.3 \\
25 & 22,458 & 75.6 & 12.4 & 58.5 \\
40 & 17,187 & 78.1 & 12.7 & 56.5 \\
60 & 15,470 & 79.3 & 12.4 & 64.3 \\
80 & 13,642 & 81.5 & 11.5 & 65.9 \\
100 & 13,934 & 85.5 & 12.2 & 68.6 \\
150 & 34,570 & 89.6 & 13.8 & 71.0 \\
200 & 31,154 & 91.8 & 15.3 & 74.1 \\
250 & 24,144 & 92.5 & 17.3 & 75.3 \\
300 & 20,415 & 93.7 & 22.0 & 78.7 \\
400 & 17,530 & 94.7 & 27.0 & 80.1 \\
500 & 8,709 & 95.4 & 32.9 & 83.1 \\
$1 \mathrm{~m}$ & 11,622 & 96.3 & 41.2 & 84.8 \\
$2 \mathrm{~m}$ & 3,118 & 97.0 & 43.1 & 88.8 \\
$3 \mathrm{~m}$ & 571 & 98.6 & 51.0 & 79.2 \\
\hline All & 582 & 85.1 & 16.3 & 72.7 \\
\hline
\end{tabular}

Notes. Sample size is 240,912 observations. The first number in the third column, 52.9, means that $52.9 \%$ of individuals with estates worth between $£ 5,000$ and $£ 9,999$ are testate. 
Figure 1. Multi-Stage Framework For Charitable Bequests
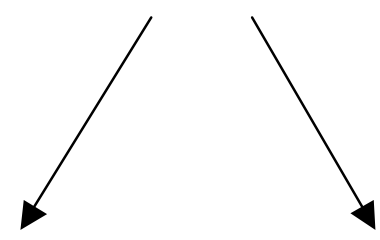

no significant wealth significant wealth

Stage 1

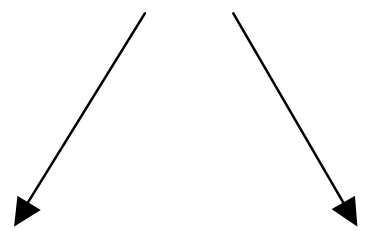

intestate (no bequests)

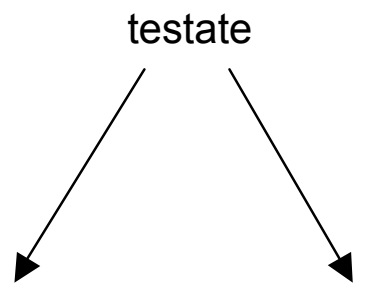

Stage 2

Stage 3

no charitable bequest

charitable bequest
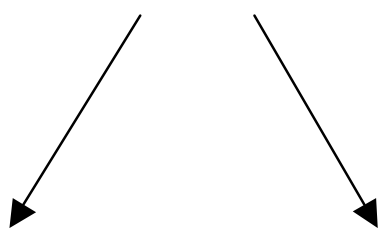

conditional

Stage 4

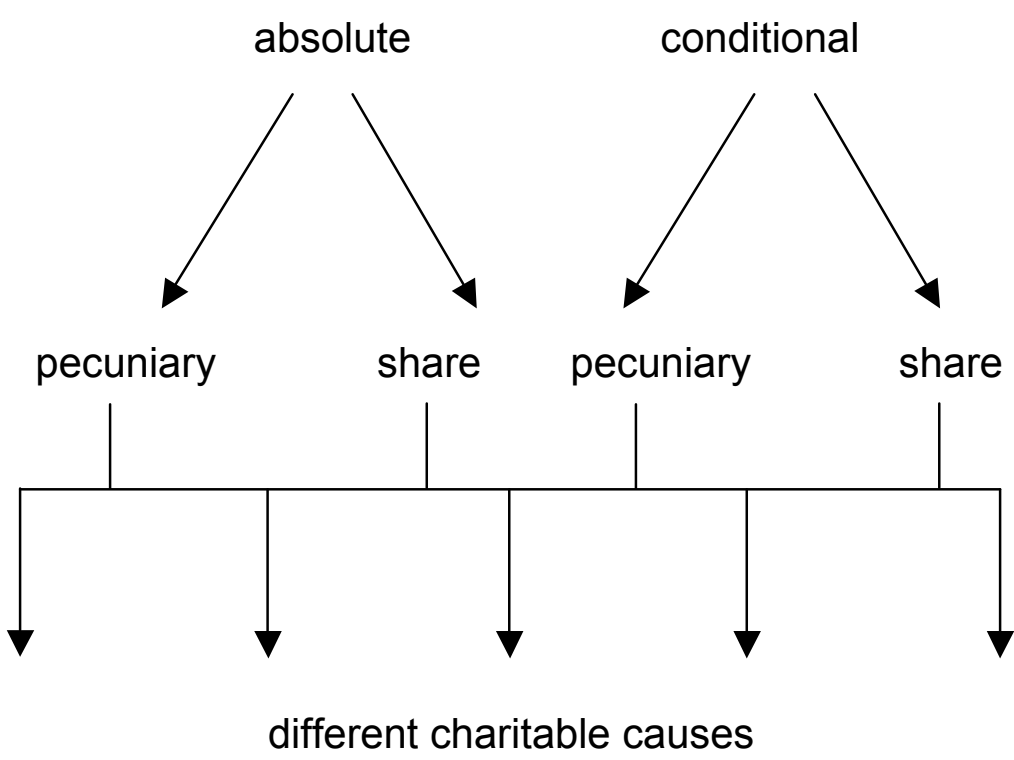

Stage 5 
Figure 2. Percentage of Decedents with 'Significant' Wealth

a) England/Wales and Scotland

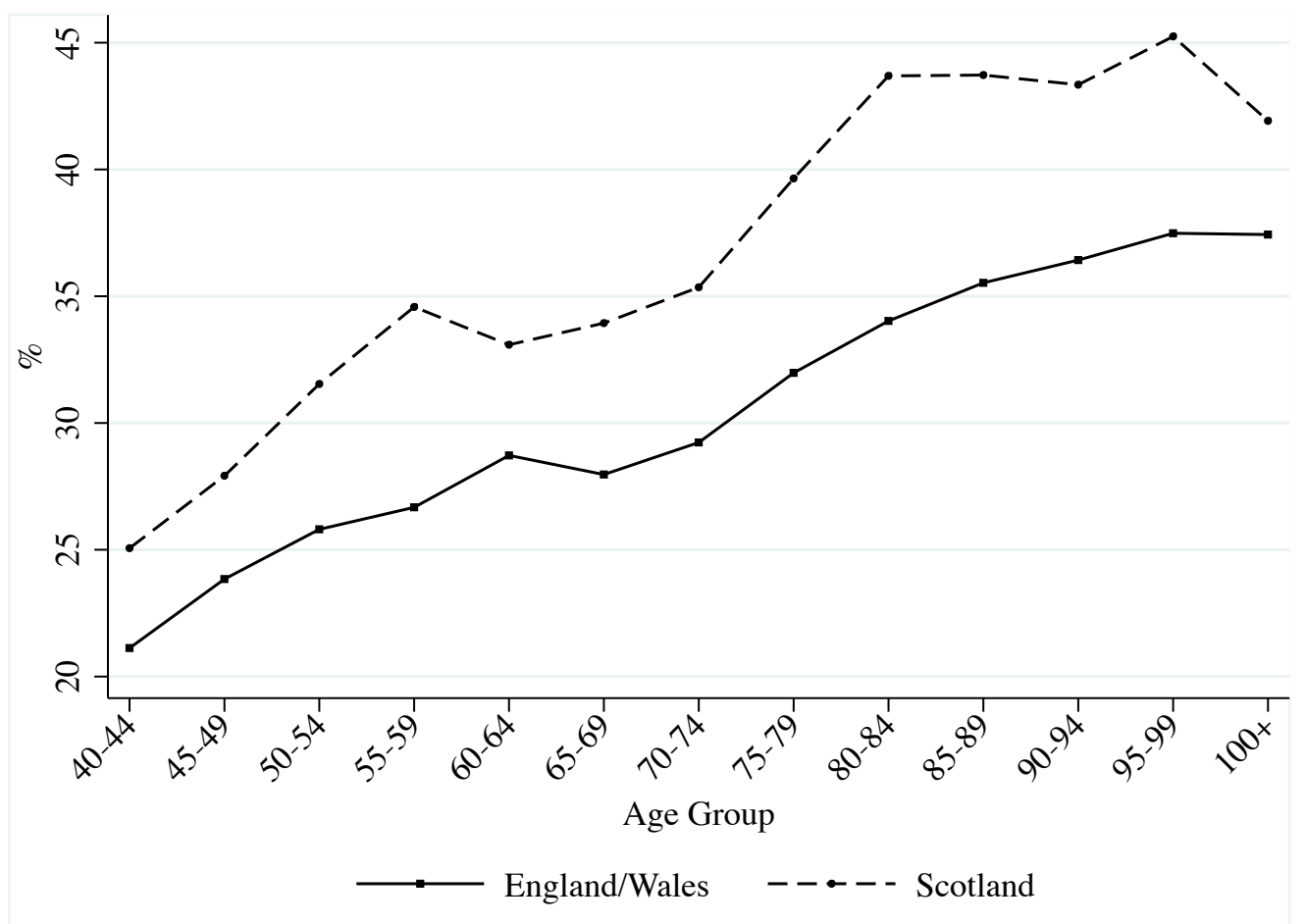

b) England/Wales

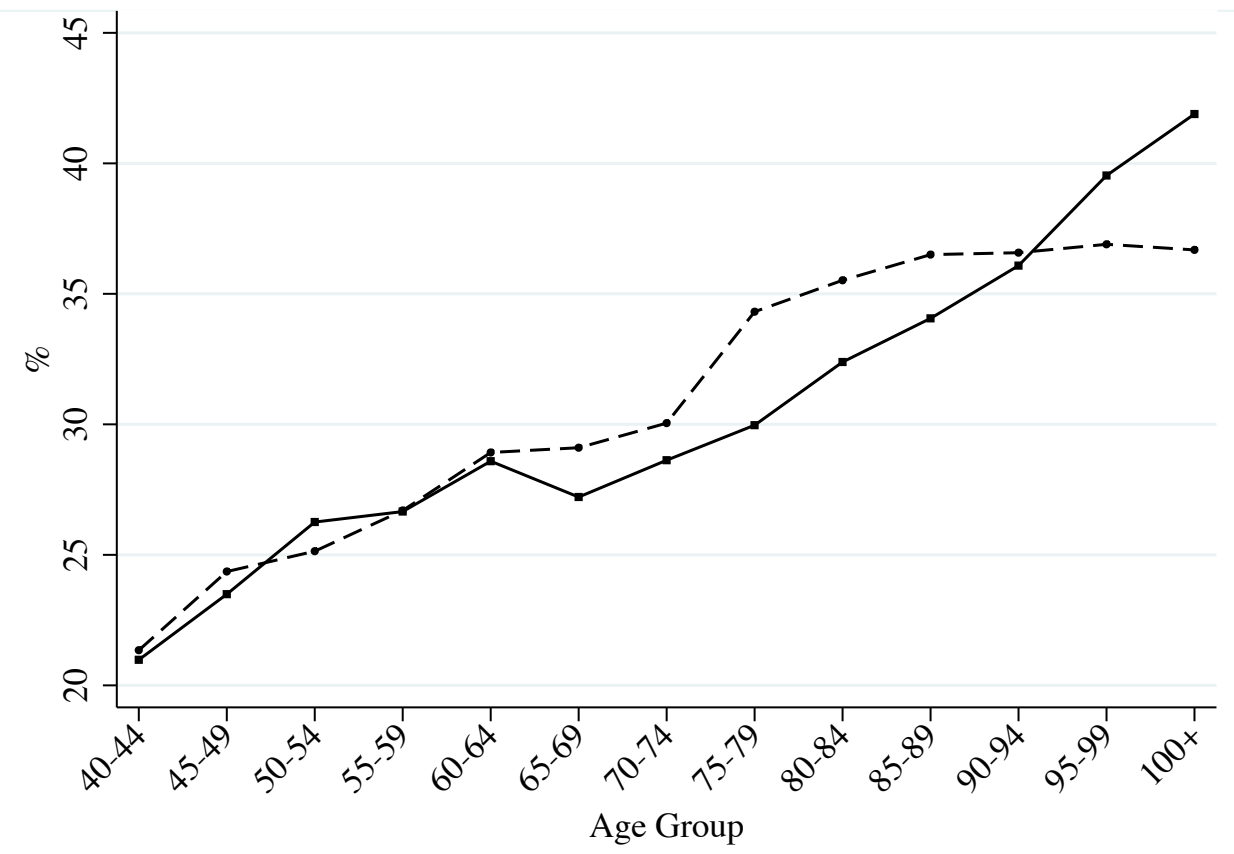

Age Group

Notes. The denominators relate to 488,103 deaths in 2007 of persons aged $40+$ in England/Wales and 53,963 in Scotland and are taken from Office for National Statistics (2008, Table 4) and General Register Office for Scotland, Vital Events Reference Tables 2007, Table 6.4 (together with personal communication with the Office to provide a breakdown for the number of deaths at age $85+$ ). 
Figure 3. Testacy, Bequeathing to Charity Conditional on Testacy, and Absolute Bequeathing Conditional on Charitable Bequeathing, by Estate Size

a) $£ 5,000$ to $£ 5$ million

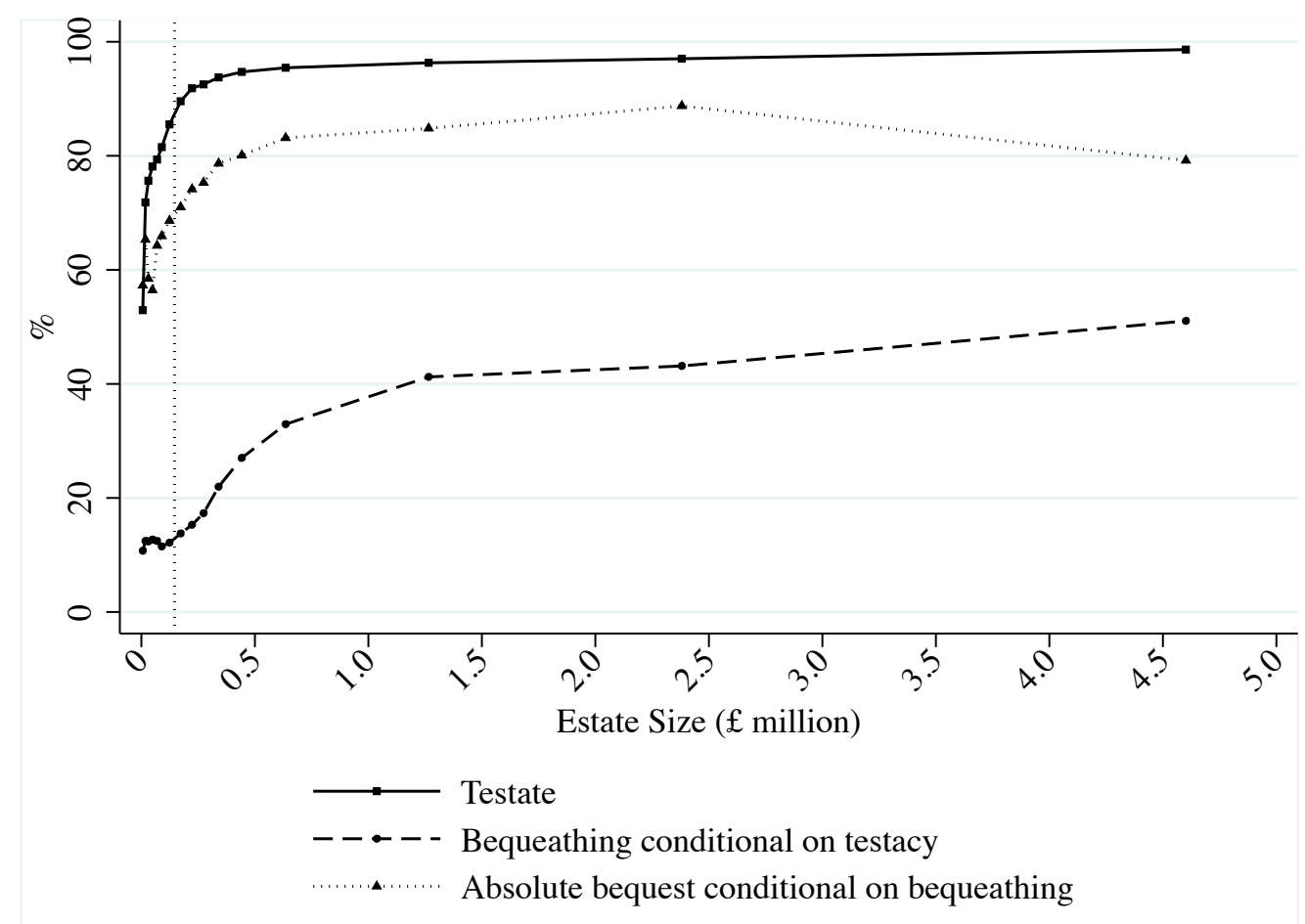

b) $£ 5,000$ to $£ 500,000$

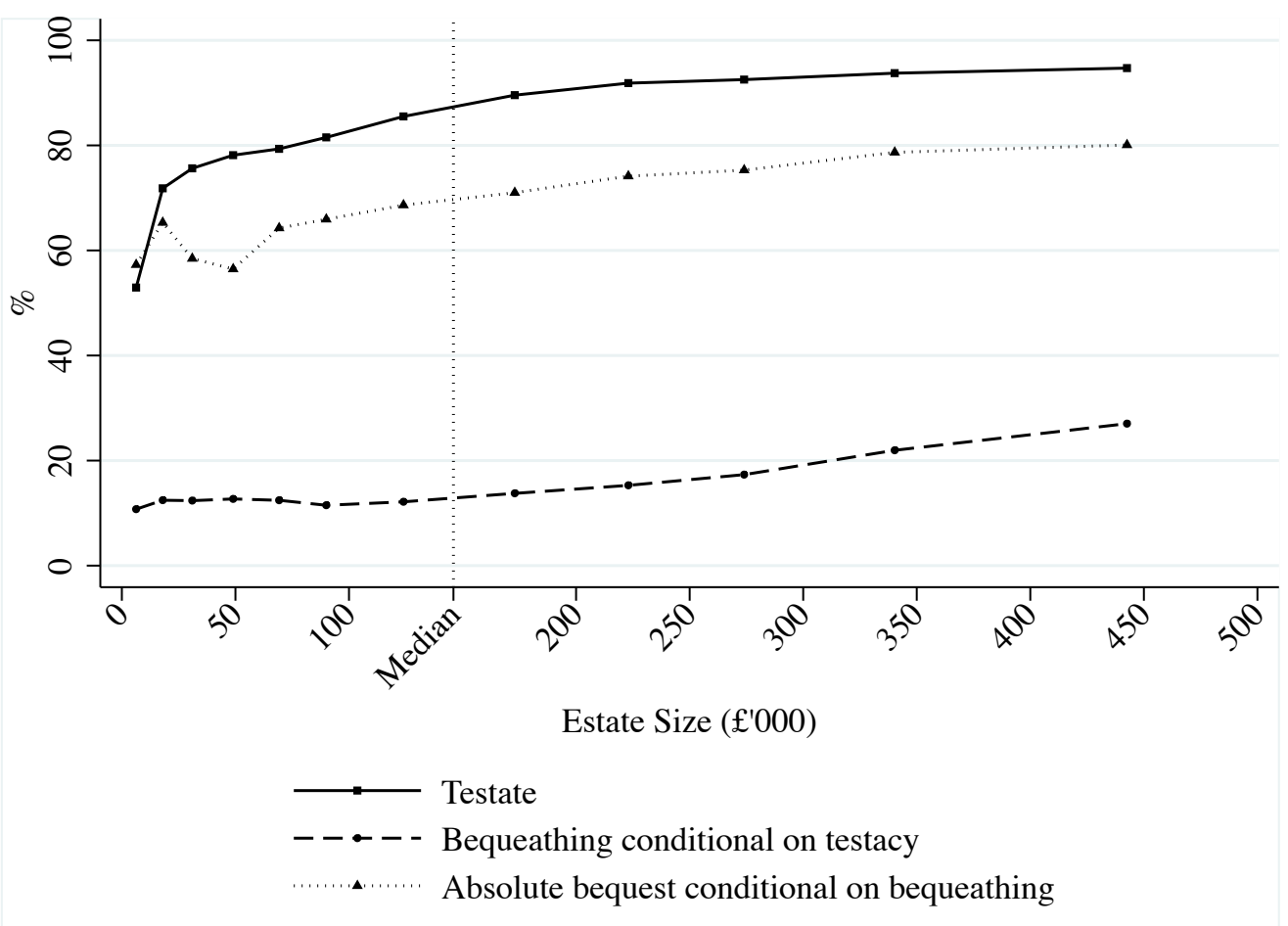

Notes. Figure 3a shows, for estates worth up to $£ 5$ million, the percentage of decedents who are testate, the percentage of testators who leave a charitable bequest and the percentage of those leaving a charitable bequest who leave at least one absolute charitable bequest. Figure 
$3 \mathrm{~b}$ shows the same for those estates worth less than $£ 500,000$. The nodes are located at the median estate size within each estate size cohort as defined in Table 2 . The vertical dotted line marks the overall median estate size of $£ 146,000$. 
Figure 4. Testacy, Bequeathing to Charity Conditional on Testacy, and Absolute Bequeathing Conditional on Charitable Bequeathing, by Age (England and Wales, Estates below $£ 300,000)$

a) Percentage of estates that are testate

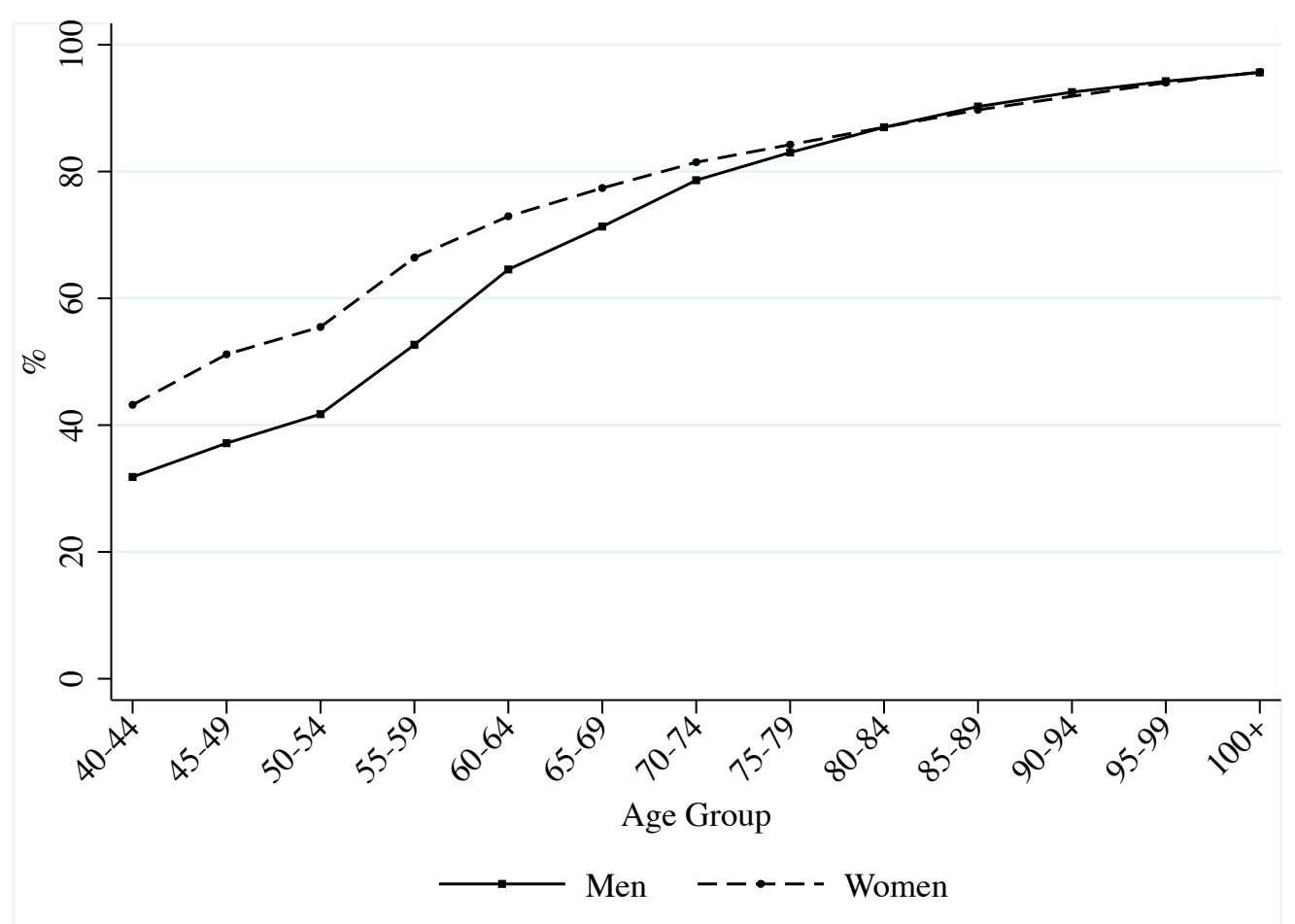

b) Percentage of testate estates containing a charitable bequest

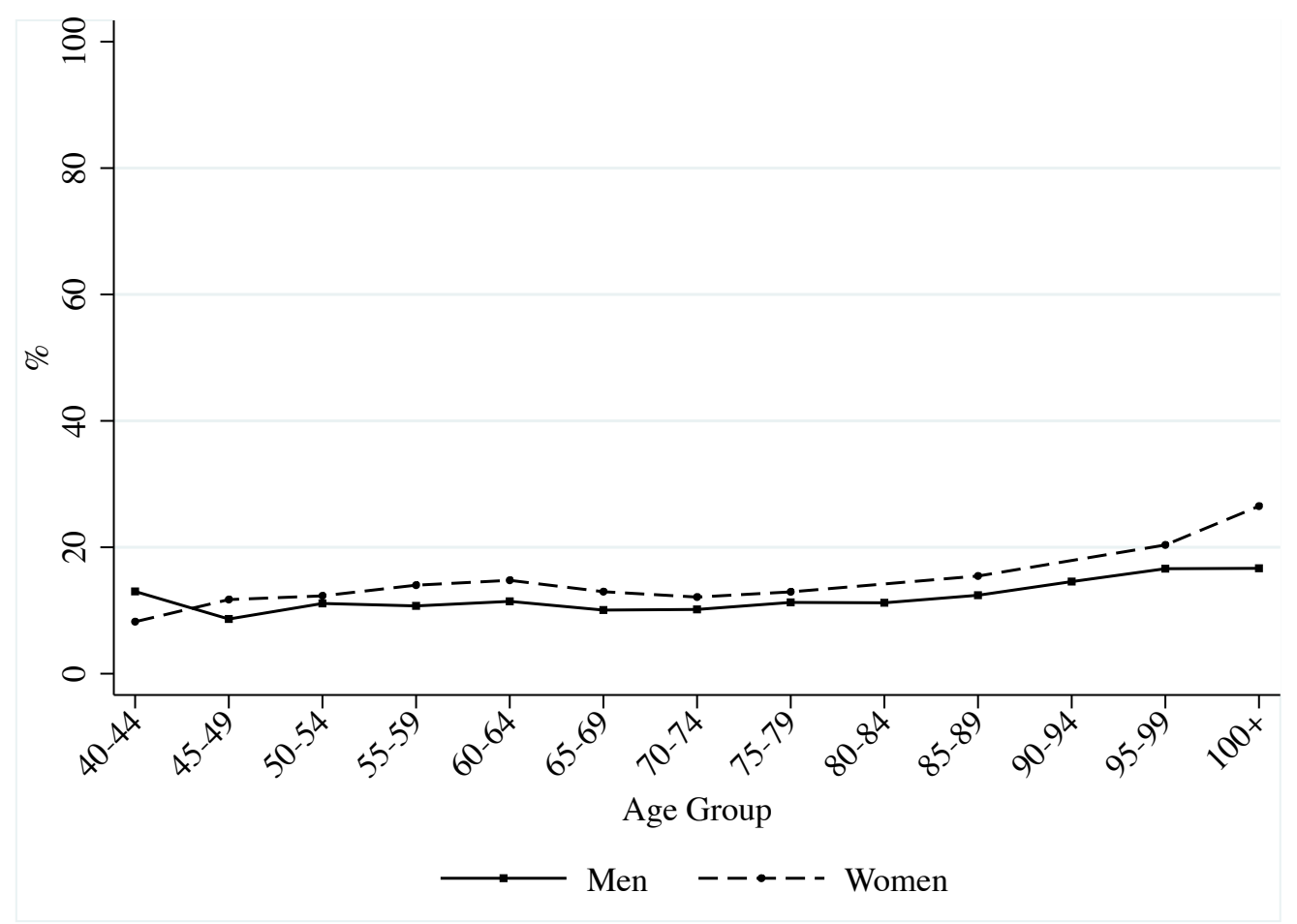


c) Percentage of charitable estates containing an absolute bequest

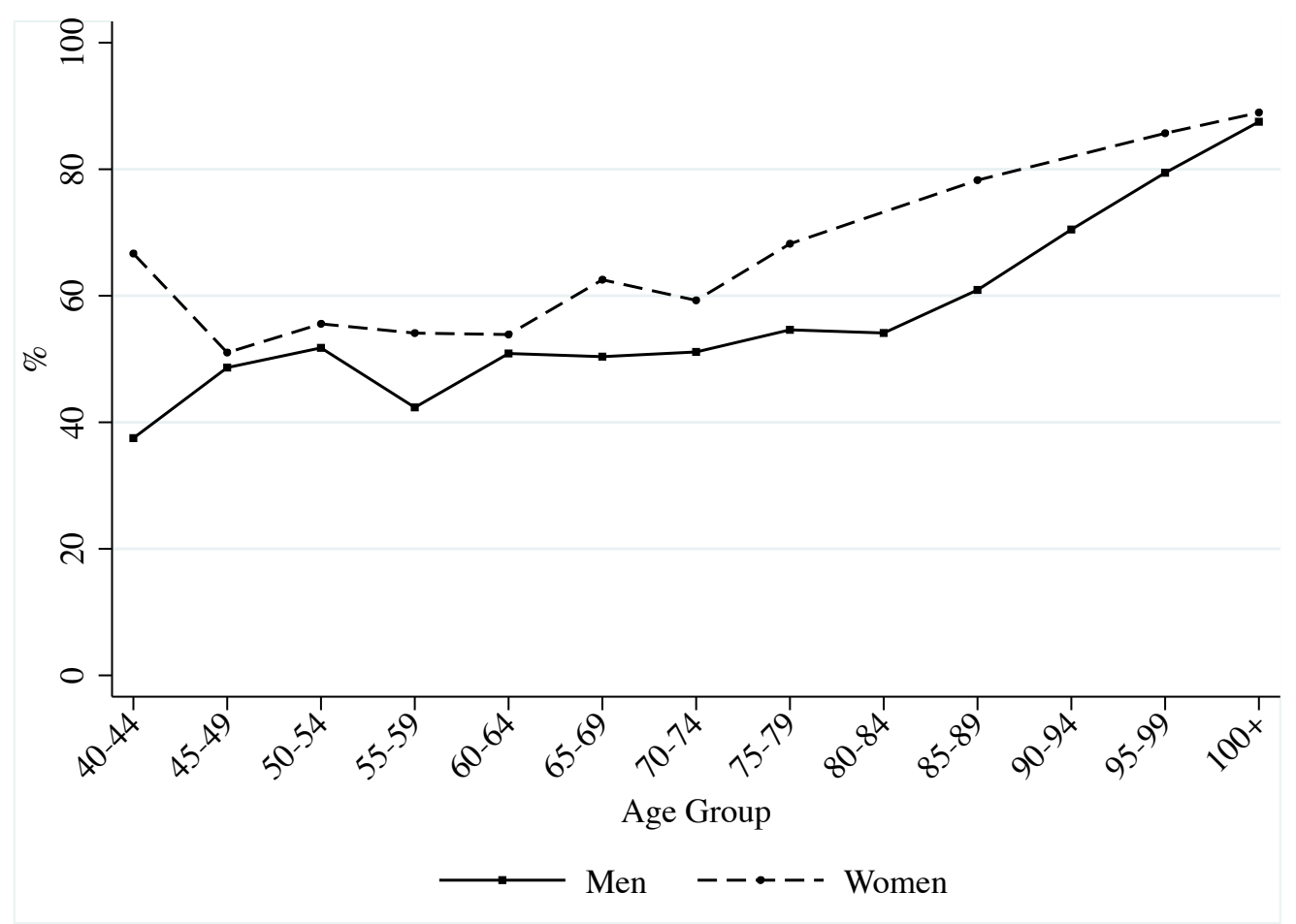

Note. Figure 4a shows the percentage of decedents that are testate, by gender over age cohort. Figure $4 \mathrm{~b}$ shows the percentage of testators that leave a charitable bequest (in any form) by gender over age cohort. Figure $4 \mathrm{c}$ shows the percentage of those leaving a charitable bequest who leave at least one absolute bequest, by gender over age cohort. The figures are constructed using a subset of our dataset that includes only estates in England and Wales worth less than $£ 300,000$. 
Figure 5a. Percentage of Estates Making a Charitable Bequest Conditional on Testacy around the IHT (Estates of $£ 200,000$ to $£ 399,999$ )

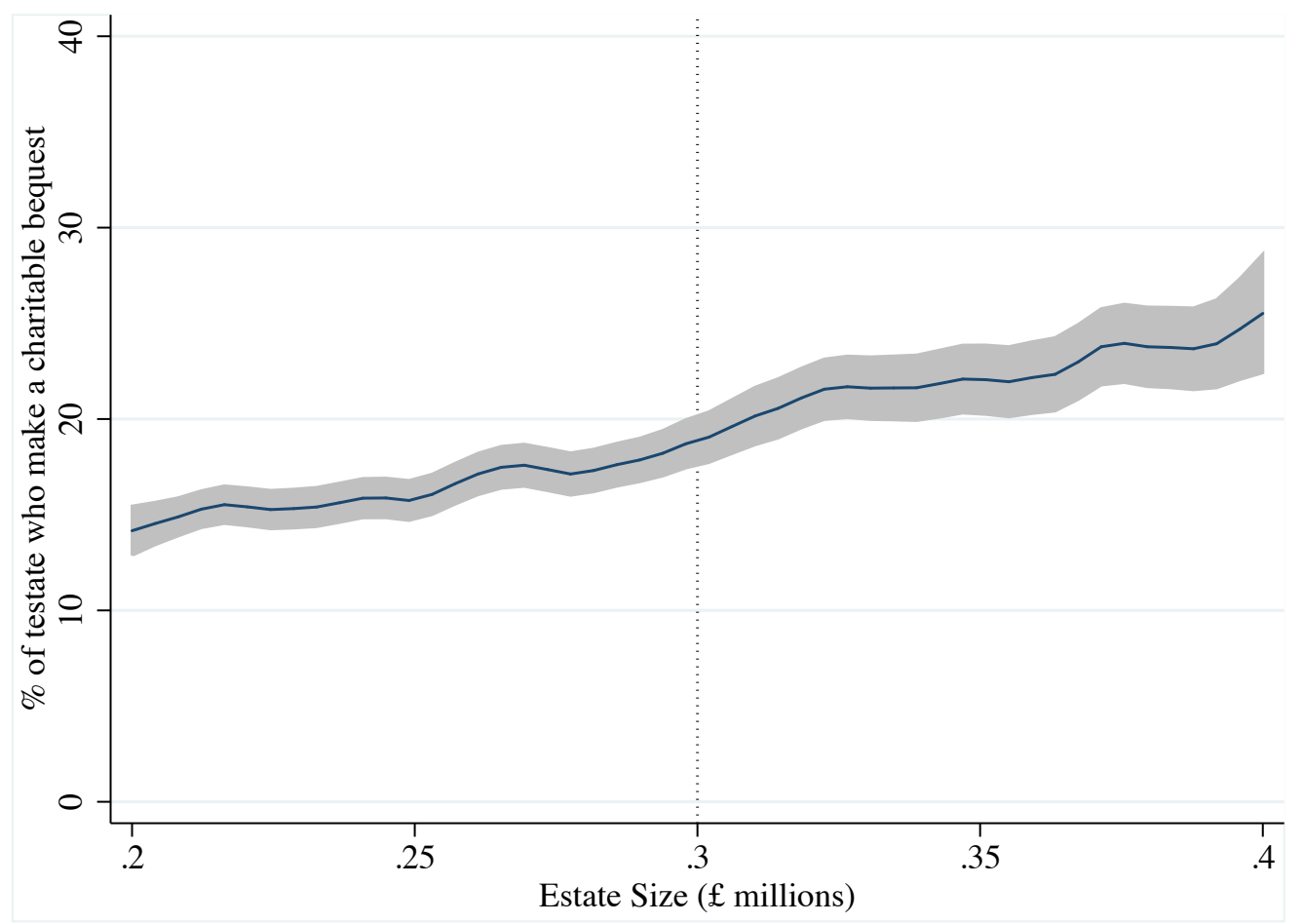

Notes. This figure is a local polynomial smoother, using an 'optimal' bandwidth from Silverman (1986), of the probability of making a charitable bequest (conditional on testacy) by estate size. A total of 57,496 estates fall with the employed range. The vertical dotted line shows the IHT threshold in April 2007-April 2008. 
Figure 5b. The Marginal Effect of Estate Size on the Probability of Making a Charitable Bequest by Estate Size (Estates of £200,000 to £599,999)

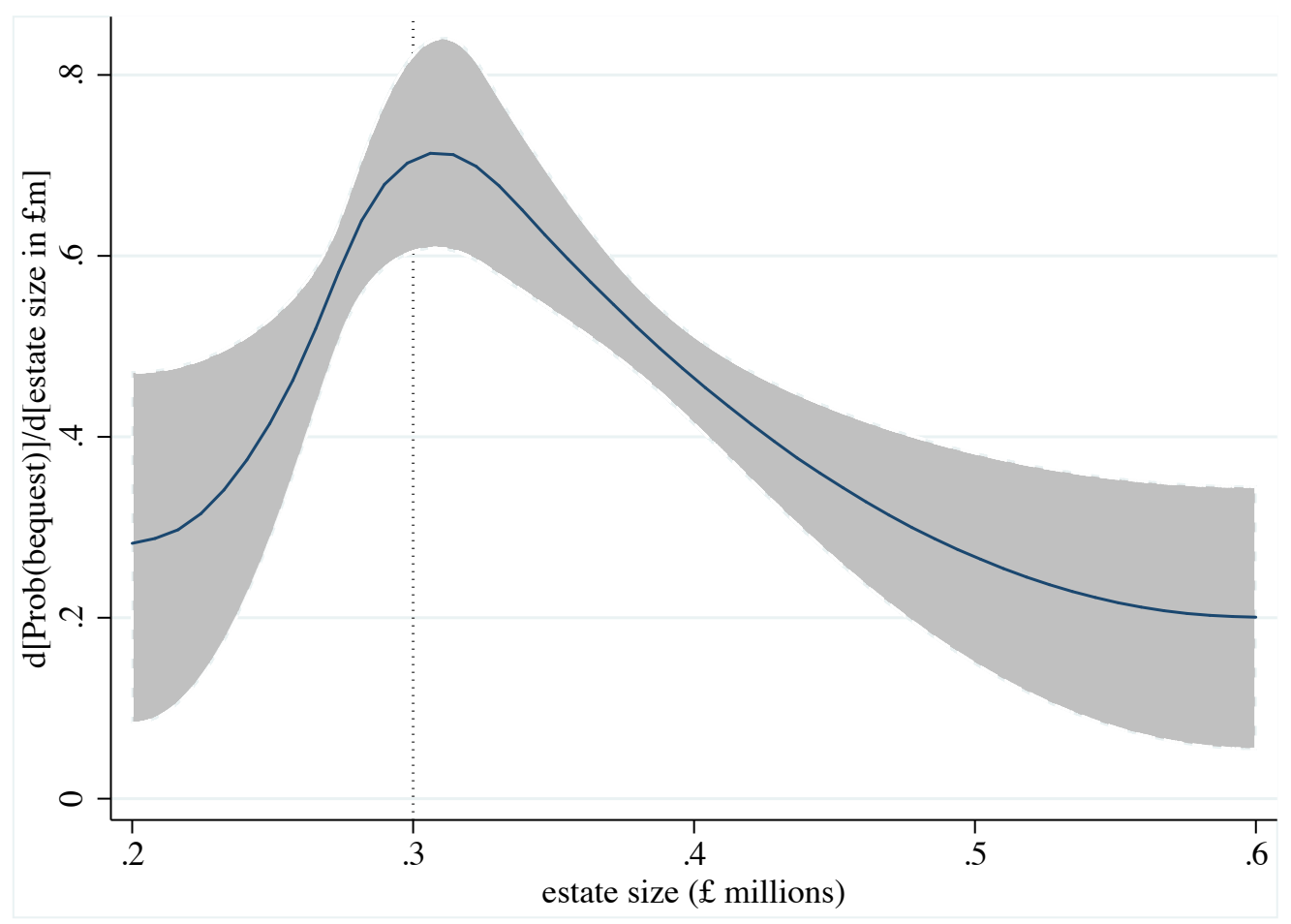

Notes. The figure plots the marginal effect of estate size on the probability of making a charitable bequest (conditional on testacy) by estate size (in $£$ millions). The marginal effects are calculated from a linear probability model with a restricted cubic spline functional form with knots located at $£ 275,000$ and $£ 325,000$. A total of 70,165 estates fall with the employed range. The vertical dotted line shows the IHT threshold in April 2007-April 2008. 
Figure 6. The Form of Charitable Bequest by Estate Size (Estates below £2 million)

a) Percentage of testate estates with absolute and conditional bequests to charity

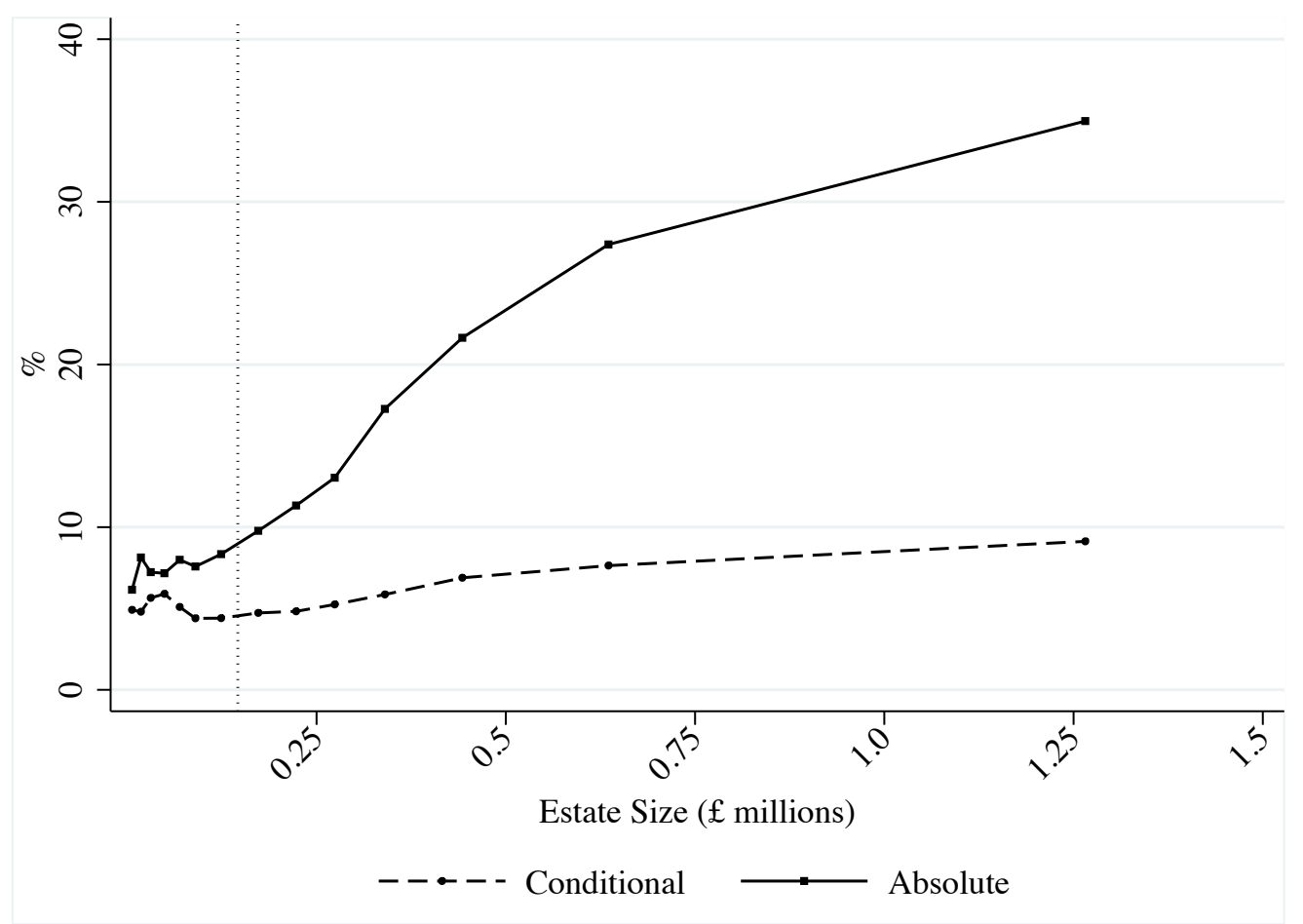

b) Percentage of testate estates with pecuniary and residual share bequests to charity

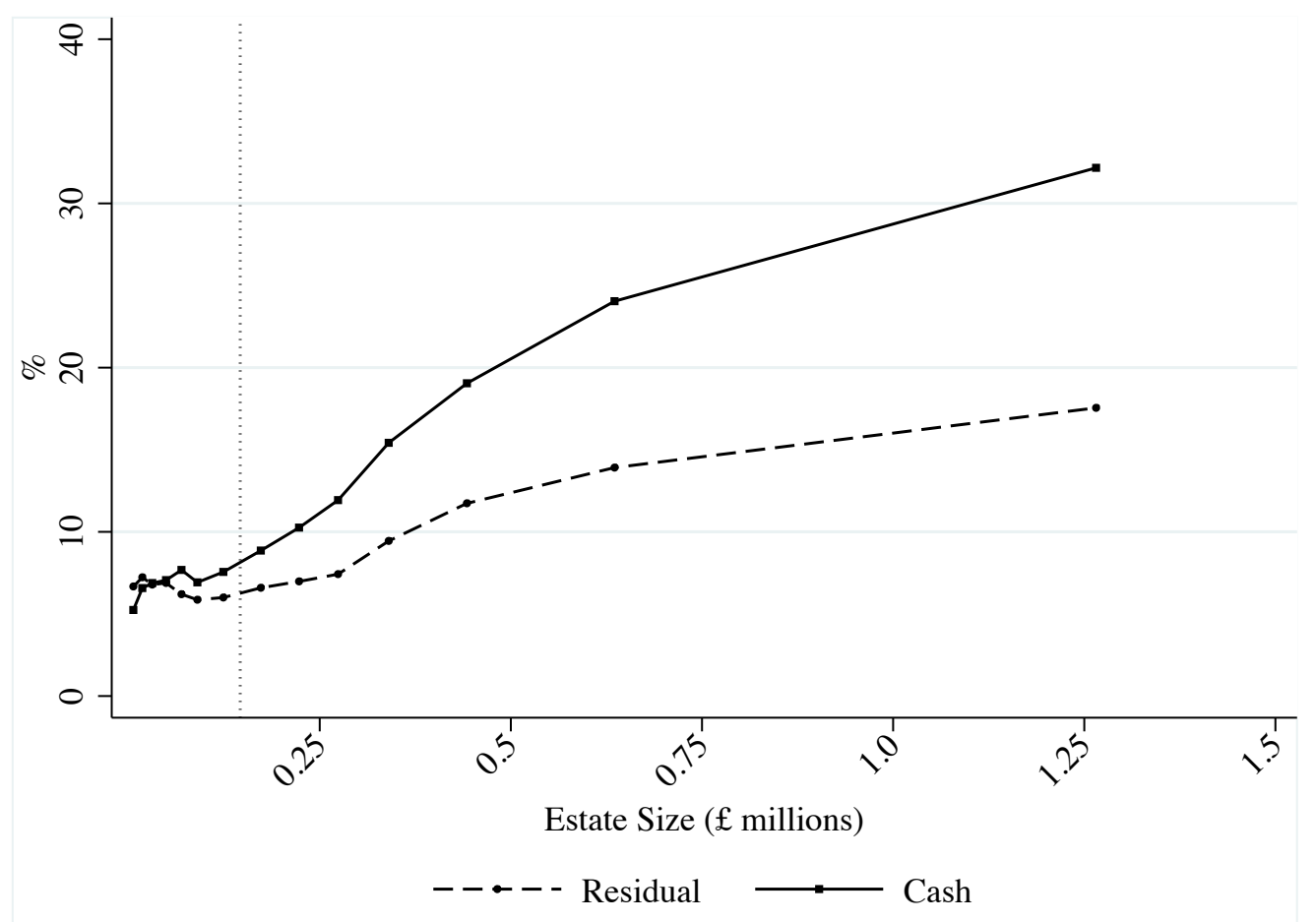

Note: Figure 6a shows the share of testate estates that leave a conditional charitable bequest or an absolute charitable bequest. Figure $6 \mathrm{~b}$ shows the share of testate estates that leave either a cash charitable bequest or a residual charitable bequest. Estates can and do leave both types of bequest, so the categories are not mutually exclusive. The nodes are located at the median 
estate size within each estate size cohort as defined in Table 2. The vertical dotted line marks the overall median estate size of $£ 146,000$. 
On-line appendix to:

\section{'Charitable bequests and wealth at death'}

Anthony B Atkinson, Peter G Backus, and John Micklewright

\section{Charitable bequests by cause}

Of particular interest to both government policy-makers and charities is the distribution of giving by cause. If we return to the theoretical model of Section 2 of the main paper, we can see that the implications depend on the source of the utility derived from bequests. Where the utility is of the "warm-glow" variety, and the donor is simply concerned with the sum left, this is quite consistent with giving to a single cause, although it provides little guidance as to the choice of cause, since no account is taken of the likely benefits from the use of the funds. In contrast, the "public good" motive for giving may suggest a strategy of diversification. Testators may have tastes for a variety of charitable causes, as they do in their inter-vivos giving (Micklewright and Schnepf, 2009). And where decisions may be made many years in advance, there is an evident risk that a particular cause may become redundant or its activities may have been taken over by government. Dawson et al (2003: 192) note that, over time, in Northern Ireland, the establishment of the National Health Service led to a switch from supporting core health services to giving to charities concerned with prevention.

The empirical literature on charitable bequests by cause is sparse. As was noted by Feldstein (1976: 102), the fourfold categorization of bequests by recipient used in the early IRS studies left the large majority in the residual category. Attention has however been drawn to the specialization of giving. In the study by Joulfaian (1991), of the 13,492 estates in the sample, 2,554 made charitable bequests. Of these, over half $(1,307)$ reported only 1 category of recipient (out of 6). He describes this concentration as 'puzzling'. Some studies have looked at the number of causes to which bequests are made. The amount bequeathed to each cause has also been analyzed and both Boskin (1976) and Barthold and Plotnick (1984) found bequeathing to religious causes to be much less wealth elastic than other causes.

In our British data, where the will contains a charitable bequest, Smee \& Ford record the main cause of the charity concerned and of each charity if there is more than one bequest. A total of 20 categories of causes are identified. On average, people leave bequests to 2.3 causes, which may be compared with the mean number of charitable bequests of $3.2-$ the difference reflecting the fact that some people leave more than one bequest to the same cause. The modal value is one -39 per cent of people leave bequests to a single cause, and a further 
23 per cent of estates have bequests to two causes. In this sense, there is, as found in the US by Joulfaian (1991), considerable concentration. However, a minority of estates show a substantial amount of diversification: 9 per cent have bequests to six or more causes.

Figure A1 shows how the average number of causes per charitable estate - an estate with a bequest of any form to charity - in each estate band up to $£ 2 \mathrm{~m}$. The figure rises from under 2 to over 3, and thereafter flattens out at higher levels of wealth (not shown). Those with more wealth at death are more diversified in their charitable bequest behaviour. The graph also shows the average number of charitable bequests, which rises more steeply, from about $2 \frac{1}{2}$ to 5 . Higher levels of wealth at death are in part associated with giving to more causes but also with multiple bequests to the same causes.

The wealthy leave bequests to more charitable causes but do they bequeath to different causes? Or do they just add on further causes while still leaving bequests to those favoured by persons with only modest estates? For each of the 20 causes identified in our data, Table A1 shows the percentage of all charitable estates that contain at least one bequest to the cause together with the percentages in large estates and in small estates, where large and small are defined as $£ 500,000$ or more and less than $£ 40,000$ respectively. (Together, the large and small estates account for 1 in 5 of all charitable estates.) We have sorted the causes on the basis of the figures in column (5), which show the percentage of large estates containing a bequest to the cause in question divided by the percentage of small estates with a bequest.

The answer to the question posed above is that the wealthy tend to add on causes: there is no cause for which the ratio in the final column is less than 1.0, that would indicate that the percentage of large estates containing a bequest to the cause in question falls notably below that for small estates. Animal welfare is the only cause where decedents with large estates have a lower propensity and the difference is very slight; in both cases around 1 in 4 estates contain a bequest. Conditional on bequeathing to charity, those with large and small estates are also equally likely to give to cancer research. Of the five most popular causes overall, the only one where the ratio for large to small estates approaches 2.0 is nursing/care. The five causes with the highest values of the ratio -3.0 or over - are human rights, the environment, culture, education, and the residual category 'other causes'. (Note that none of these are among the five most popular causes for those with large estates, and one - human rights - is among the least popular.) The percentage of the wealthy decedents leaving bequests to causes grouped under this last heading is particularly high for very large estates 1 in 5 charitable estates of $£ 2 \mathrm{~m}$ or more contain a bequest to charities classified in this group. 
This represents about 1 in 10 of all estates of this size, including those with no charitable bequests. This residual category includes bequests to charities for which Smee \& Ford have been unable to identify the charitable purpose, for example a bequest to a charitable trust named after the decedent where there is no indication as to the cause that the charity serves. In this way, the wealthy may be able to bequeath to charity but have considerable influence over the use of the assets bequeathed through appointment of chosen trustees prior to the date of death.

The cause with the biggest ratio is education. Given that a bequest to charity is made, large estates are over $4 \frac{1}{2}$ times more likely than small ones to contain a bequest to this cause. And taking into account all testate estates, including those with no charitable bequests, large estates are about 15 times more likely to have a bequest to education than small estates, whereas they are only about $3 \frac{1 / 2}{2}$ times more likely to contain a bequest to an animal charity. ${ }^{1}$

\section{References}

Atkinson A.B., Backus, P.G. and Micklewright, J. (2009). 'Charitable bequests and wealth at death in Great Britain', Working Paper A09/03, Southampton Statistical Sciences Research Institute.

Barthold, T. and Plotnick, R. (1984). 'Estate taxation and the other determinants of charitable bequests', National Tax Journal, vol. 37(2), pp. 225-37.

Boskin, M.J. (1976). 'Estate taxation and charitable bequests', Journal of Public Economics, vol. 5(1), pp. 27-56.

Dawson, N., Grattan, S., Lundy, L., Glenn, R. and Cran, G. (2003). Dying to Give? Trends in Charitable Giving by Will, London: The Stationery Office.

Feldstein, M.S. (1976). 'Charitable bequests, estate taxation, and intergenerational wealth transfers' in R.E. Grieson, editor, Public and Urban Economics, Lexington Books, Lexington.

Joulfaian, D. (1991). 'Charitable bequests and estate taxes', National Tax Journal, vol. 44(2), pp. 169-80.

Micklewright, J. and Schnepf, S. (2009). 'Who gives charitable donations for overseas development?', Journal of Social Policy, vol. 38(2), pp. 317-41.

\footnotetext{
${ }^{1}$ There are only modest differences between men and women in the pattern of support for different causes (Atkinson, Backus and Micklewright, 2009, Table 10).
} 
Figure A1. Average number of bequests and number of causes by estate size (estates below $£ 2$ million)

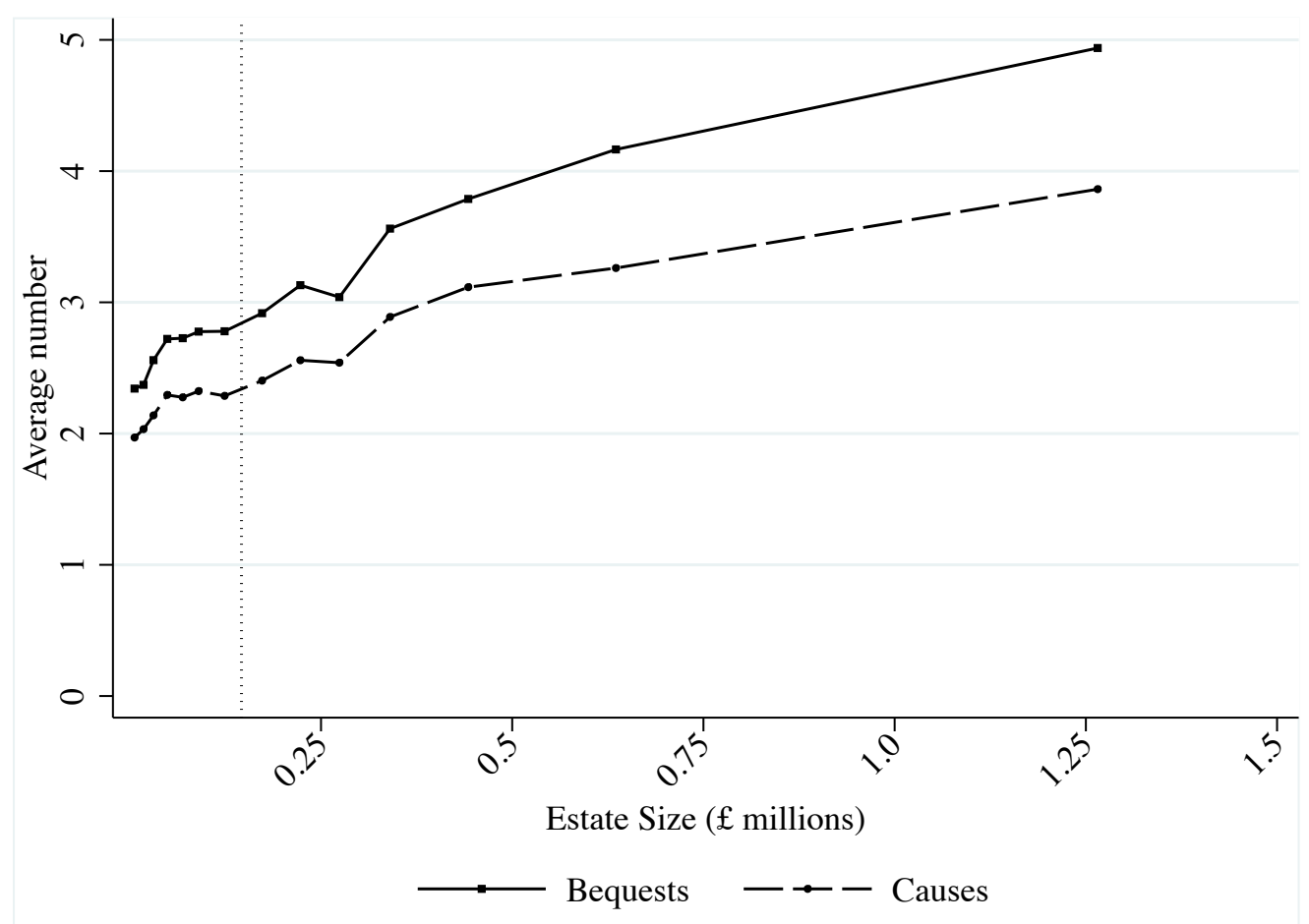

Note: This figure shows the average number of charitable bequests made and the average number of causes to which they are made. The nodes are located at the median estate size within each estate size cohort as defined in Table 2 . The vertical dotted line marks the overall median estate size of $£ 146,000$. 
Table A1: Charitable bequeathing by cause

\begin{tabular}{lrrrr}
\hline$(1)$ & \multicolumn{1}{c}{$(2)$} & $(3)$ & $(4)$ & $(5)$ \\
Cause & $\begin{array}{c}\text { \% of charitable estates with a } \\
\text { bequest to the cause }\end{array}$ & $\begin{array}{c}\text { Ratio of } \\
\text { (4) to (3) }\end{array}$ \\
\hline Animal & All estates & $<£ 40 \mathrm{k}$ & $\geq £ 500 \mathrm{k}$ & \\
Cancer Research & 24.9 & 25.0 & 24.2 & 1.0 \\
Hospices/Hospitals & 22.8 & 21.7 & 22.7 & 1.0 \\
Medical Research & 25.4 & 22.5 & 27.1 & 1.2 \\
Religious & 17.1 & 14.6 & 19.0 & 1.3 \\
Worship & 7.6 & 6.8 & 9.0 & 1.3 \\
Physical Disability & 26.4 & 20.9 & 31.3 & 1.5 \\
Family Issues & 14.8 & 12.2 & 19.4 & 1.6 \\
Child Welfare & 0.3 & 0.3 & 0.4 & 1.6 \\
Mental Health & 9.9 & 7.8 & 13.4 & 1.7 \\
Rescue Services & 3.5 & 2.7 & 4.7 & 1.7 \\
Nursing/Care & 11.7 & 8.5 & 15.2 & 1.8 \\
Aged & 20.3 & 14.8 & 28.4 & 1.9 \\
Overseas Aid & 6.9 & 5.6 & 11.2 & 2.0 \\
Services & 8.9 & 5.9 & 12.4 & 2.1 \\
Human Rights & 6.3 & 4.3 & 9.8 & 2.3 \\
Other & 1.8 & 1.1 & 3.2 & 3.0 \\
Environment & 6.4 & 3.6 & 11.2 & 3.1 \\
Culture & 4.6 & 2.2 & 7.5 & 3.4 \\
Education & 6.6 & 3.1 & 12.6 & 4.0 \\
\hline
\end{tabular}

Notes: Rows are ordered by the values in the last column in ascending order. There are 3,947 charitable estates of less than $£ 40,000$ and 5,424 of more than $£ 500,000$. In total, 33,482 estates contained a charitable bequest. The first number in column (2) indicates that among all estates that contain a charitable bequest, $24.9 \%$ include at least one bequest to a charity working for animals. 